\title{
Origins of Injection-Site Sarcomas in Cats: The Possible Role of Chronic Inflammation-A Review
}

\author{
Kevin N. Woodward ${ }^{1,2}$ \\ ${ }^{1}$ Technology Sciences (Europe) Limited, Concordia House, St James Business Park, Grimbald Crag Court, Knaresborough, \\ North Yorkshire, HG5 8QB, UK \\ ${ }^{2}$ Intervet/Schering-Plough Animal Health, Breakspear Road South, Harefield, Uxbridge, Middlesex, UB9 6LS, UK \\ Correspondence should be addressed to Kevin N. Woodward, kevin.woodward@tsgeurope.com
}

Received 17 January 2011; Accepted 13 February 2011

Academic Editors: M. Malkinson and A. Pratelli

Copyright ( $) 2011$ Kevin N. Woodward. This is an open access article distributed under the Creative Commons Attribution License, which permits unrestricted use, distribution, and reproduction in any medium, provided the original work is properly cited.

\begin{abstract}
The etiology of feline injection-site sarcomas remains obscure. Sarcomas and other tumors are known to be associated with viral infections in humans and other animals, including cats. However, the available evidence suggests that this is not the case with feline injection-site sarcomas. These tumors have more in common with sarcomas noted in experimental studies with laboratory animals where foreign materials such as glass, plastics, and metal are the causal agent. Tumors arising with these agents are associated with chronic inflammation at the injection or implantation sites. Similar tumors have been observed, albeit infrequently, at microchip implantation sites, and these also are associated with chronic inflammation. It is suggested that injection-site sarcomas in cats may arise at the administration site as a result of chronic inflammation, possibly provoked by adjuvant materials, with subsequent DNA damage, cellular transformation, and clonal expansion. However, more fundamental research is required to elucidate the mechanisms involved.
\end{abstract}

\section{Introduction}

The majority of cancers of humans and other animals are carcinomas. These are tumours of epidermal origin that can invade and metastasise and which may ultimately prove fatal. Another group of malignant tumours are the sarcomas. These are tumours, probably of mesenchymal origin that, like carcinomas, are also locally invasive and have the ability to metastasise and again, are also found in humans [14]. In cats and dogs, a variety of soft tissue sarcomas may arise spontaneously including fibrosarcoma, myxosarcoma, liposarcoma, neurofibrosarcoma, malignant Schwannoma, rhabdomyosarcoma, and leiomyosarcoma [5-7]. Although these tumours are amenable to treatment, local recurrence is common after resection and they are locally invasive; those with a diameter of $>5 \mathrm{~cm}$ show a poor response to radiotherapy and to chemotherapy [3,7-17].

One of the results of veterinary pharmacovigilance has been the recognition of the development of sarcomas at the injection site in cats following routine vaccination and occasionally, following administration of pharmaceutical products [18-29]. These tumors are usually fibrosarcomas. As with spontaneous fibrosarcomas, many of those associated with injection sites show a variety of morphological and subcellular abnormalities [30-34]. They are frequently fast growing and aggressive and may spread locally and aggressively along fascial planes and metastasise to remote sites [12, 35-41]. These tumors tend to consist of elongated cells supported by a fibrovascular stroma. Areas of necrosis are reported to be common along with infiltrates of lymphocytes, macrophages, and multinucleate giant cells, and there are higher mitotic rates than are noted in noninjection site sarcomas [18, 31, 32, 42, 43]. Like spontaneously occurring sarcomas, they are challenging to treat $[10,16,37,44-49]$. There have been a number of case reports of such tumours following vaccination $[19,20,23,50-55]$. Additionally, there have been reports on rhabdomyosarcoma, malignant fibrous histiocytoma, chondroma, sarcoma, myofibrosarcoma, and liposarcoma developing at the injection site in cats [43, 50, 56-58]. As with spontaneously occurring tumors, these injection-associated sarcomas are amenable to treatment. This normally involves radiotherapy and chemotherapy with 
various agents including carboplatin, doxorubicin (including doxil, a doxorubicin hydrochloride liposome formulation), cyclophosphamide and vincristine as well as immunotherapy; such treatments provide remission but many cats will finally succumb to the disease $[8,44,59-65]$.

It should be emphasised that the frequency of these injection-site tumours is rare [66-69]. For example, the prevalence in the US was estimated to be 0.00021 cases/cat visit or 2.1 cases per 10000 cat visits for 1992 [66]. Moreover, the undoubted benefits of vaccination against serious and frequently fatal infectious diseases clearly outweigh the risks associated with vaccination. Nevertheless, the frequency of these lesions, or their diagnostic recognition, does appear to be increasing $[24,25,27,38,42,43,53,56,57,69-82]$. For example, in the United Kingdom, the number of reports of injection-site sarcomas associated with vaccines submitted to the regulatory agency, the Veterinary Medicines Directorate (VMD) has risen over the period from 2001 to 2008 [83-91]. In 2009, the latest year for which figures were available, 40 reports were submitted to the VMD [91].

Despite considerable research over the last few decades since the phenomenon was first noted, there is currently no plausible explanation for the development of fibrosarcomas in cats at the injection site.

\section{Possible Etiologies}

Virus-associated cancers, including sarcomas, are wellknown tumours of cats but where these have been sought in injection-site associated lesions, they have not been found $[32,92,93]$. Other explanations must be sought. In a review of human sarcomas, one authority notes that there is case history evidence for the development of sarcomas at the site of repeated trauma or foreign body implants [1]. He goes on to say that this is nonsense because it assumes the pre-existence of a dormant sarcoma at the injury site. So the roles of repeated trauma or of foreign bodies in the development of fibrosarcomas can be dismissed. Or can they? Other evidence notably from toxicology and experimental pathology might suggest otherwise.

Grasso and Golberg demonstrated the induction of sarcomas in rats after the subcutaneous injection of certain food colourings [94]. Some food colorants such as Patent Blue $\mathrm{V}$ produced no appreciable tissue reaction while others including Brilliant Blue FCF led to an intense macrophage response with macrophage necrosis and proliferation of fibroblasts. Other food colourings produced the development of collagenous material with a "persistent fibroblastic reaction." The colorants which produced these tissue reactions were also shown to result in fibrosarcomas at the injection sites despite the fact that the substances tested were not classical chemical carcinogens.

Similar findings in rats and mice have been noted with other substances some of which were carcinogens while others, notably iron derivatives, some polymeric rubber additives, polyvinyl pyrrolidones, vitamin E, soya oil, and Tween 80, were clearly not [95-107]. Leaving frank carcinogens aside, it was noted that the otherwise biologically inert materials which did lead to intense tissue reactions and injection site sarcomas were those which possessed surface activity, acidic $\mathrm{pH}$ or precipitated at the site of injection [103, 107-110].

Furthermore, subcutaneous implanting of solid materials including various polymers, including Cellophane, plastic films, hydrophilic Millipore discs, Bakelite, Teflon, glass, and particulate plastic materials, has resulted in sarcomagenesis in rats and mice [111-134]. As with the chemicals discussed above, the formation of sarcomas was preceded by fibrosis and the production of collagenous material [123, 125, 134]. It appears that there may be a biphasic response with an initial phase involving cellular proliferation and tissue infiltration and later, fibrosis $[135,136]$. The carcinogenic process is thought to involve inflammation, with reactive oxygen species playing an important role in the ensuing genetic damage $[137,138]$.

Together, these findings gave rise to the terms foreignbody sarcomas or more broadly, solid state carcinogenesis [139]. They also gave rise to concerns over implants, prostheses, and medical devices used in human medicine but the available evidence does not suggest these are associated with undue risks, certainly from the point of view of local fibrosarcoma induction [140-150] although there have been cases of various sarcomas including osteosarcoma, Ewing's sarcoma, and angiosarcoma associated with prostheses and vascular grafts [151-153]. Cancers have been reported at the sites of shrapnel injuries where fragments have remained for several years [154-156]. Moreover, there have been reports that intramuscular injections of various drugs, but notably iron compounds, have given rise to granulomas, as well as sarcomas and other tumours at the injection site [157-165]. Unfortunately, the diverse nature of the drugs (iron dextran, diclofenac, insulin zinc (Lente), and penicillin) and the fact that some patients were receiving immunosuppressive therapy make the available data difficult to interpret. Any risks, especially with iron compounds, are likely to be very small [166, 167]. Nevertheless, all of these findings, and notably those from animal studies, raise questions on the role of inflammation in the induction of tumors.

\section{The Possible Role of Chronic Inflammation}

Vaccines are composed of antigenic materials dissolved or suspended in solution. The antigens are unlikely to be carcinogenic and solvent systems are carefully chosen for safety. Many inactivated vaccines also contain adjuvants or immunopotentiators [168-170]. Veterinary vaccines are subjected to rigorous safety testing and evaluation prior to authorisation $[171,172]$ but vaccination is not without risks in humans, and in animals although these risks are low $[29,173-178]$.

Many inactivated veterinary vaccines contain aluminium hydroxide, an insoluble aluminium compound, or other aluminium derivatives as adjuvant [170] and in companion animals such as dogs and cats, these vaccines are frequently given subcutaneously. Could this aluminium material be behaving as a foreign-body carcinogen in the cat? There is some evidence for this. 
The cat certainly seems susceptible to fibrosarcomas as the data on vaccines already reviewed here demonstrates. Moreover, fibrosarcomas have been reported in cats at the site of microchip implantation [179] and at the site of a nonabsorbale suture [180]. Interestingly, although the injection site-associated sarcoma story has largely focussed on cats, they have also been noted in the dog [181] while, sarcomas adjacent to microchip implantation have also been observed in this species [182, 183]. Microchips have been shown to elicit sarcomas in mice [184]. An osteosarcoma has been reported at the site of a retained surgical sponge in the dog [185]. Aluminium has been detected in an injectionsite sarcoma resected from a cat $[32,92]$. Using electron probe microanalysis, aluminium was detected in a number of injection-site sarcomas obtained from cats [186].

These observations do not provide conclusive proof that aluminium is involved in foreign-body carcinogenesis in the cat (or dog). However, aluminium is relatively inert as indeed are microchips and many of the plastics, films, and metals employed in the experimental studies discussed above. So, what possible mechanism could be involved?

Unfortunately, there are not too many (known) options. The immediate reaction to a foreign body is acute inflammation, a protective mechanism which aims to remove the foreign body for example, by the killing and lysis of bacterial cells. It is of short duration and characterised by exudation of fluid and plasma proteins and migration of leukocytes. It involves a number of humoral and cellular mediators including histamine, serotonin, prostaglandins, cytokines, nitric oxide, and reactive oxygen species, and following removal of the offending object, resolution occurs.

If the foreign body cannot be removed, for example, because it is insoluble-a metal particle, glass fragment, plastic, or if a persistent infection exists, for example, in tuberculosis, schistosomiasis, and with Treponema pallidum, then chronic inflammation may take over [137]. Indeed, chronic inflammation may occur from the outset. The socalled foreign body reaction and chronic inflammation are synonymous [138, 187]. Chronic inflammation involves monocytes, macrophages, lymphocytes, plasma cells and fibroblasts and is also mediated by a range of substances including the complement system, cytokines, growth factors, and reactive oxygen species. The end point is tissue destruction and fibrosis, and the condition is a disease in its own right. Granuloma formation, the aggregation of macrophages accompanied by lymphocytes, may also occur. Chronic inflammation is associated with cancer. Indeed, over recent years, that association has grown stronger and a range of tumours has now become linked with chronic inflammation in humans including carcinoma of the prostate, lung, pancreas, stomach and bowel, and other organs [188-204].

Chronic inflammatory bowel diseases including Crohn's disease and ulcerative colitis, as well as conditions that result in chronic inflammation such as oesophageal reflux and laryngeal inflammation, may predispose to cancer [205-209]. Sarcomas have been shown to develop at the site of chronic tropical ulcers [210]. In chickens infected with Rous sarcoma virus, a known oncogenic virus, inflammation appears to be responsible for sarcoma induction at the site of experimentally inflicted wounds, possibly mediated by TGF- $\beta$ and other factors, and released by inflammatory cells at the site of injury [211-220]; TGF- $\beta$ is a major mediator of fibrosis and may promote tumor development through immunosuppression and the initiation of angiogenesis, possibly through signalling involving the Smad pathway [221-224]; mice lacking Smad3 show accelerated wound healing and a reduced local inflammatory response [225, 226]. Indeed, wounds or other tissue damage may promote carcinogenesis through the involvement of growth factors regardless of the origins of the tumor [227-232]. This may involve the activation of toll-like receptors initiating inflammation $[233,234]$. Chronic inflammation in the form of emphysema, possibly mediated by cytokines and chemokines, may lead eventually to lung cancer [235]. Whatever initially led to the underlying disease, the chronic inflammation may be seen as the forerunner, or even the cause of cancer.

As an example, schistosomiasis (bilharzia) is associated with the development of bladder cancer in humans [236$244]$. Why should a parasitic infection lead to tumours of this nature (not to mention the intestine, liver, and uterus)? The parasites cause physical damage to the mucosa and urothelium leading to hyperplasia, but they also, possibly along with bacteria, result in chronic inflammation [218, 243]. In these cancers, chromosomal damage and mutations, including mutations in the p53 suppressor gene have been found, and these may be due to oxygen radicals persistently produced by the cells characteristic of chronic inflammation, notably by macrophages, neutrophils, and eosinophils [241, 243, 245-247].

A similar picture exists with gastric cancer in humans. It has been recognised in recent years that gastric cancer is linked to chronic infection with Helicobacter pylori, gastric ulceration and chronic inflammation [137, 238, 248-253]. Although the genesis of this tumor is multifactorial, chronic inflammation plays a major role $[253,254]$. Carcinogenesis accompanying gastroesophageal reflux is also associated with chronic inflammation [255].

In this way, these infections may reflect similar effects noted in chemical carcinogenesis. For example, some nongenotoxic carcinogens including butylated hydroxyanisole (BHA), caffeic acid, and sesamol cause forestomach tumors in rats through irritant effects which over prolonged periods of administration result in chronic inflammation while others which produce urolithiasis, irritation, and chronic inflammation such as uracil, melamine, and sodium saccharin result in cancers of the bladder and urinary tract [256265].

There are several other chemicals, generally regarded as nongenotoxic, which may exert carcinogenic effects through the medium of oxidative stress, chronic inflammation and reactive oxygen species. These include bile acids, silica, arsenic, and substances which lead to renal tumours in male rats through a hyaline droplet nephropathy involving $\alpha_{2 \mu^{-}}$ globulin [266-275]. DNA strand breaks have been noted in cells in the fibrotic capsule in rats following implantation of foreign bodies [187]. 
The association between chronic inflammation, oxidative stress, and reactive species and carcinogenesis, even in the absence of genotoxic effects, is very strong [109, 249, 276-292]. Indeed, DNA damage resulting from chronic inflammation and linked to reactive oxygen and nitrogen species, has been shown to contribute to carcinogenesis of the colon in mice [285]. DNA damage, including DNA methylation is also a direct consequence of many nongenotoxic carcinogens [286]. Consequently, a scenario can be envisaged where a foreign body (or other source) can induce acute inflammation through the intermediacy of eicosanoids or vasoactive amines and then with a failure in resolution, or de novo by way of tumor necrosis factor (TNF), growth factors, and other cytokines and chemokines [192, 253, 293301] a self-perpetuating chronic inflammation ensues with responses by a number of cells and notably macrophages and fibroblasts [302-304]. As these cells then continue to destroy or phagocytose the foreign body, through inter alia the employment of lipoxygenases, cyclooxygenases, and other enzymes, free radicals are generated which can then result in genotoxic damage $[277,278,282,286,305]$ possibly with the involvement of stem cells [305] and the development of tumors. Chronic inflammation may also be involved in the subsequent processes of invasion and metastasis, particularly through leukocyte infiltration and associated chemokines [188, 283, 305-307].

Oxidative stress and DNA damage induced by genotoxic and nongenotoxic agents (including TNF- $\alpha$ ) activates the tumor suppressor protein p53 and other central regulatory genes [279, 308-312]. This protein has a complex range of functions including the arrest of cells in the cell cycle, permanent cell cycle arrest, and the initiation of apoptosis [308, 313-324], a process that, in addition to other functions, removes defective or damaged cells [325-328]. In human cancers, there is a high rate of mutations in the p53 gene and inactivation of p53 thus facilitates tumorigenesis in humans and in animals [329-340]. In human skin carcinogenesis, inactivation of the p53 gene and the onset of genomic instability are the earliest events in the process [341].

Hence, the p53 gene and its protein are not only major factors in cell cycle control, especially in carcinogenesis, the protein itself is an indicator and biomarker of DNA damage and mutagenesis and if suppressed, cell proliferation will ensue [45, 312, 342-349]. Some oncogenic viruses have evolved mechanisms to negate the effects of p53 [350]. Some genotoxic carcinogens may also disrupt apoptosis through disruption of growth control proteins such as c-myc or Bcl-2 [320, 351].

So, is there any evidence that vaccines or aluminiumbased adjuvants can induce any of these events? A study of feline vaccine-associated sarcomas showed just over $51 \%$ to be surrounded by macrophages and lymphocytes with granulomatous reactions; similar indicators of chronic inflammation have been noted in other experimental studies [30, $31,186,352]$. In dogs, injection-site sarcomas have inflammatory infiltrates including lymphocytes, macrophages, and plasma cells [181]. In an experimental study, cats treated with adjuvanted vaccine, including an aluminium-based adjuvant, had more inflammation than those treated with nonadjuvanted vaccines. Moreover, there was evidence of residual adjuvant material at the injection site [353]. Lipidadjuvanted vaccines also resulted in inflammation in cats at the injection site [354]. In humans, aluminium adjuvants may function through stimulating dendritic cells, cells which play a major role in the process of inflammation [355].

Experimental studies show that foreign body reactions in dogs involve granulomatous reactions typical of chronic inflammation [356]. A cat which developed a sarcoma adjacent to the site of a microchip insertion had evidence of a cellular response typical of chronic inflammation [179]. Similar findings were made in dogs implanted with microchips [357], including in a dog that developed a fibrosarcoma near to a microchip insertion site [183]. Inflammation has been noted in B6C3F1 mice at the site of microchip-induced sarcomas [184]. Mild inflammation and granulomatous reactions were seen in mice implanted with microchips [358, 359]. Interestingly, microchips resulted in sarcomas at the site of microchip implantation in heterozygous $\mathrm{p}^{3} 3^{+/-}$mice; this was associated with increased oxidative and nitrative stress [360, 360].

In several studies, $\mathrm{p} 53$ protein has been detected in these feline sarcomas [65, 361-364]. Loss of p53 heterozygosity and loss of p53 function has been observed in $\operatorname{Trp} 53^{+/-}$ mice implanted with subcutaneous plastic plates. These mice developed sarcomas at the implantation site [360]. There was evidence of oxidative and nitrative stress in these animals as a result of implantation. Oxidative stress is associated with the process of carcinogenesis [365-370].

\section{Discussion}

In conclusion, some of the injection-site associated sarcomas seen in cats (and occasionally in dogs), as well as the microchip associated sarcomas, may be examples of foreign body tumours associated with foreign material, probably insoluble aluminium compounds (or microchips) which results in inflammation, failure of resolution, chronic inflammation, and subsequent DNA damage and cell proliferation, with the induction of p53 as a counter measure to suppress the process of carcinogenesis through disruption of the cell cycle and initiation of apoptosis. The process is similar to the sarcomagenesis seen in experimental studies with a variety of agents including food colorants, plastics, and metals. Mutations of p53 have been found in some feline and canine soft-tissue sarcomas [371-373]. Nanosized titanium dioxide has been shown to be cytotoxic to PC12 cells (derived from rat adrenal medulla pheochromocytoma) and results in oxidative stress, probably through the accumulation of reactive oxygen species, and apoptosis [374], a situation which may mimic the effects of vaccine adjuvants in vivo. The finding of metalloproteinase expression in feline injection-associated sarcomas supports the involvement of an inflammatory mechanism [375] a process shown to promote tumour growth in mice [376].

The situation may also be similar to that seen with asbestos-related mesothelioma in humans. Among the mechanisms envisaged for asbestos-related carcinogenicity, with ample data to support it, is chronic inflammation of the 
mesothelium with cytokine release, infiltration of inflammatory cells, reactive species and DNA damage and induction of p53 [377-381].

However, not all vaccines contain insoluble adjuvants and injection site sarcomas have been noted in animals after injection of pharmaceutical products. Hence, the role of insoluble material may not be critical. This raises the possibility that wounding itself, the process of injection, may be involved and, as discussed earlier, wounding and trauma, with an accompanying inflammatory process, may be involved in sarcomagenesis. None of this explains why the cat is so susceptible to the induction of these tumors or indeed, why they frequently appear in animals at a very young age. Although there is some evidence for the occurrence of these tumors in dogs, the incidence is extremely low compared with that in cats. Humans are given a variety of vaccines and injectable drugs over the course of a life-time but, apart from a few reports, there is no firm evidence to indicate that these treatments lead to tumor induction at the site of administration. All of this may suggest that the cat has a genetic predisposition to injection-site-related sarcomas, or at least to the damage related to injection which ultimately predisposes to sarcomagenesis. This may help to explain the cat's susceptibility to ocular sarcomas, some of which occur at the site of previous trauma [382-388].

Vaccines are important prophylactic tools that protect against a range of debilitating and frequently fatal diseases in animals and in humans while pharmaceutical products are vital in the treatment of disease. The low levels of risk from injection-associated side-effects must be weighed against the undoubted benefits of these products. Through the processes built into modern pharmacovigilance procedures it is important to constantly monitor these effects, including injection-site sarcomas in companion animals, and notably in cats. As has been noted recently for human vaccines, the risks and benefits must be continually evaluated [389] and this is allowed in modern pharmacovigilance practices.

\section{References}

[1] J. G. Sinkovics, "Adult human sarcomas. I. Basic science," Expert Review of Anticancer Therapy, vol. 7, no. 1, pp. 31-56, 2007.

[2] J. G. Sinkovics, "Adult human sarcomas. II. Medical oncology," Expert Review of Anticancer Therapy, vol. 7, no. 2, pp. 183-210, 2007.

[3] D. E. Thrall and E. L. Gillette, "Soft-tissue sarcomas," Seminars in Veterinary Medicine and Surgery, vol. 10, no. 3, pp. 173-179, 1995.

[4] E. G. MacEwen, "Spontaneous tumors in dogs and cats: models for the study of cancer biology and treatment," Cancer and Metastasis Reviews, vol. 9, no. 2, pp. 125-136, 1990.

[5] J. M. Liptak and L. J. Forrest, "Soft tissue sarcomas," in Withrow and MacEwen's Small Animal Clinical Oncology, S. J. Withrow and D. M. Vail, Eds., pp. 425-454, Saunders Elsevier, St Louis, Miss, USA, 4th edition, 2006.

[6] S. M. Liu and I. Mikaelian, "Cutaneous smooth muscle tumors in the dog and cat," Veterinary Pathology, vol. 40, no. 6, pp. 685-692, 2003.
[7] D. M. Vail and E. G. MacEwen, "Spontaneously occurring tumors of companion animals as models for human cancer," Cancer Investigation, vol. 18, no. 8, pp. 781-792, 2000.

[8] L. G. Barber, K. U. Sørenmo, K. L. Cronin, and F. S. Shofer, "Combined doxorubicin and cyclophosphamide chemotherapy for nonresectable feline fibrosarcoma," Journal of the American Animal Hospital Association, vol. 36, no. 5, pp. 416421, 2000.

[9] D. E. Bostock and M. T. Dye, "Prognosis after surgical excision of fibrosarcomas in cats," Journal of the American Veterinary Medical Association, vol. 175, no. 7, pp. 727-728, 1979.

[10] C. G. Couto and D. W. Macy, "Review of treatment options for vaccine-associated feline sarcoma," Journal of the American Veterinary Medical Association, vol. 213, no. 10, pp. 1426-1427, 1998.

[11] K. Cronin, R. L. Page, G. Spodnick et al., "Radiation therapy and surgery for fibrosarcoma in 33 cats," Veterinary Radiology and Ultrasound, vol. 39, no. 1, pp. 51-56, 1998.

[12] E. B. Davidson, C. R. Gregory, and P. H. Kass, "Surgical excision of soft tissue fibrosarcomas in cats," Veterinary Surgery, vol. 26, no. 4, pp. 265-269, 1997.

[13] K. M. Davis, E. M. Hardie, F. R. Martin, J. Zhu, and C. Brownie, "Correlation between perioperative factors and successful outcome in fibrosarcoma resection in cats," Veterinary Record, vol. 161, no. 6, pp. 199-200, 2007.

[14] W. S. Dernell, S. J. Withrow, C. A. Kuntz, and B. E. Powers, "Principles of treatment for soft tissue sarcoma," Clinical Techniques in Small Animal Practice, vol. 13, no. 1, pp. 59-64, 1998.

[15] D. E. Hilmas and E. L. Gillette, "Radiotherapy of spontaneous fibrous connective tissue sarcomas in animals," Journal of the National Cancer Institute, vol. 56, no. 2, pp. 365-368, 1976.

[16] C. A. Novosad, "Principles of treatment for vaccineassociated sarcomas," Clinical Techniques in Small Animal Practice, vol. 18, no. 2, pp. 115-117, 2003.

[17] K. M. Rassnick, C. O. Rodrigues, C. Khanna et al., "Results of a phase II clinical trial on the use of ifosfamide for treatment of cats with vaccine-associated sarcomas," American Journal of Veterinary Research, vol. 67, no. 3, pp. 517-523, 2006.

[18] D. Aberdein, J. S. Munday, C. B. Dyer, C. G. Knight, A. F. French, and I. R. Gibson, "Comparison of the histology and immunohistochemistry of vaccination-site and nonvaccination-site sarcomas from cats in New Zealand," New Zealand Veterinary Journal, vol. 55, no. 5, pp. 203-207, 2007.

[19] G. Burton and K. V. Mason, "Do postvaccinal sarcomas occur in Australian cats?" Australian Veterinary Journal, vol. 75, no. 2, pp. 102-106, 1997.

[20] M. M. G. De Man and R. V. Ducatelle, "Bilateral subcutaneous fibrosarcomas in a cat following feline parvo-, herpesand calicivirus vaccination," Journal of Feline Medicine and Surgery, vol. 9, no. 5, pp. 432-434, 2007.

[21] D. G. Esplin, M. Bigelow, L. D. McGill, and S. R. Wilson, "Fibrosarcoma at the site of a lufenuron injection in a cat," Veterinary Cancer Society Newsletter, no. 23, pp. 8-9, 1999.

[22] A. C. Gagnon, "Drug injection-associated fibrosarcoma in a cat," Feline Practice, vol. 28, no. 2, pp. 18-21, 2000.

[23] L. T. Gemmill, "Injection-site sarcomas in cats," Journal of the American Veterinary Medical Association, vol. 213, no. 7, p. 955, 1998.

[24] P. H. Kass, W. G. Barnes, W. L. Spangler, B. B. Chomel, and M. R. Culbertson, "Epidemiological evidence for a causal relationship between vaccination and fibrosarcoma 
tumorigenesis in cats," Journal of the American Veterinary Medical Association, vol. 203, no. 3, pp. 396-405, 1993.

[25] D. W. Macy, "Current understanding of vaccination siteassociated sarcomas in the cat," Journal of Feline Medicine and Surgery, vol. 1, no. 1, pp. 15-21, 1999.

[26] E. A. McNiel, "Vaccine-associated sarcomas in cats: a unique cancer model," Clinical Orthopaedics and Related Research, no. 382, pp. 21-27, 2001.

[27] S. C. Shaw, M. S. Kent, I. K. Gordon et al., "Temporal changes in characteristics of injection-site sarcomas in cats: 392 cases (1990-2006)," Journal of the American Veterinary Medical Association, vol. 234, no. 3, pp. 376-380, 2009.

[28] K. N. Woodward, "Veterinary pharmacovigilance. Part 2. Veterinary pharmacovigilance in practice-the operation of a spontaneous reporting scheme in a European Union country-the UK, and schemes in other countries," Journal of Veterinary Pharmacology and Therapeutics, vol. 28, no. 2, pp. 149-170, 2005.

[29] K. N. Woodward and L. Toon, "Adverse reactions to vaccines," in Veterinary Pharmacovigilance, K. N. Woodward, Ed., pp. 453-473, John Wiley \& Sons, Chichester, UK., 2009.

[30] E. E. Carroll, R. R. Dubielzig, and R. D. Schultz, "Cats differ from mink and ferrets in their response to commercial vaccines: a histologic comparison of early vaccine reactions," Veterinary Pathology, vol. 39, no. 2, pp. 216-227, 2002.

[31] S. S. Couto, S. M. Griffey, P. C. Duarte, and B. R. Madewell, "Feline vaccine-associated fibrosarcoma: morphologic distinctions," Veterinary Pathology, vol. 39, no. 1, pp. 33-41, 2002.

[32] B. R. Madewell, S. M. Griffey, M. C. McEntee, V. J. Leppert, and R. J. Munn, "Feline vaccine-associated fibrosarcoma: an ultrastructural study of 20 tumors (1996-1999)," Veterinary Pathology, vol. 38, no. 2, pp. 196-202, 2001.

[33] B. Mayr, U. Eschborn, and M. Kalat, "Near triploidy in a feline fibrosarcoma," Zentralblatt fur Veterinarmedizin. Reihe A, vol. 38, no. 8, pp. 617-620, 1991.

[34] B. Mayr, B. Bockstahler, G. Loupal, M. Reifinger, and W. Schleger, "Cytogenetic variation between four cases of feline fibrosarcoma," Research in Veterinary Science, vol. 61, no. 3, pp. 268-270, 1996.

[35] C. M. Briscoe, T. P. Lipscomb, and L. McKinney, "Pulmonary metastasis of a feline vaccination-site fibrosarcoma," Journal of Veterinary Diagnostic Investigation, vol. 10, no. 1, pp. 7982, 1998.

[36] D. G. Esplin, "Widespread metastasis of a fibrosarcoma associated with vaccination site in a cat," Feline Practice, vol. 23, no. 1, pp. 13-16, 1995.

[37] M. Martano, E. Morello, M. Ughetto et al., "Surgery alone versus surgery and doxorubicin for the treatment of feline injection-site sarcomas: a report on 69 cases," Veterinary Journal, vol. 170, no. 1, pp. 84-90, 2005.

[38] R. Dean, V. Adams, T. Whitbread et al., "Study of feline injection site sarcomas," Veterinary Record, vol. 159, no. 19, p. $641,2006$.

[39] G. Romanelli, L. Marconato, D. Olivero, F. Massari, and E. Zini, "Analysis of prognostic factors associated with injection-site sarcomas in cats: 57 cases (2001-2007)," Journal of the American Veterinary Medical Association, vol. 232, no. 8, pp. 1193-1199, 2008.

[40] D. G. Rudmann, W. G. Van Alstine, F. Doddy, G. E. Sandusky, T. Barkdull, and E. B. Janovitz, "Pulmonary and mediastinal metastases of a vaccination-site sarcoma in a cat," Veterinary Pathology, vol. 33, no. 4, pp. 466-469, 1996.
[41] I. Sandler, M. Teeger, and S. Best, "Metastatic vaccine associated fibrosarcoma in a 10-year-old cat," Canadian Veterinary Journal, vol. 38, no. 6, p. 374, 1997.

[42] F. D. Doddy, L. T. Glickman, N. W. Glickman, and E. B. Janovitz, "Feline fibrosarcomas at vaccination sites and nonvaccination sites," Journal of Comparative Pathology, vol. 114, no. 2, pp. 165-174, 1996.

[43] M. J. Hendrick and J. J. Brooks, "Postvaccinal sarcomas in the cat: histology and immunohistochemistry," Veterinary Pathology, vol. 31, no. 1, pp. 126-129, 1994.

[44] V. S. Bregazzi, S. M. LaRue, E. McNiel et al., "Treatment with a combination of doxorubicin, surgery, and radiation versus surgery and radiation alone for cats with vaccine-associated sarcomas: 25 cases (1995-2000)," Journal of the American Veterinary Medical Association, vol. 218, no. 4, pp. 547-550, 2001.

[45] M. Cohen, J. C. Wright, W. R. Brawner, A. N. Smith, R. Henderson, and E. N. Behrend, "Use of surgery and electron beam irradiation, with or without chemotherapy, for treatment of vaccine-associated sarcomas in cats: 78 cases (1996-2000)," Journal of the American Veterinary Medical Association, vol. 219, no. 11, pp. 1582-1589, 2001.

[46] C. Eckstein, F. Guscetti, M. Roos, J. Martín de Las Mulas, B. Kaser-Hotz, and C. Rohrer Bley, "A retrospective analysis of radiation therapy for the treatment of feline vaccineassociated sarcoma," Veterinary and Comparative Oncology, vol. 7, no. 1, pp. 54-68, 2009.

[47] A. E. Hershey, R. R. Dubielzig, M. L. Padilla, and S. C. Helfand, "Aberrant p53 expression in feline vaccineassociated sarcomas and correlation with prognosis," Veterinary Pathology, vol. 42, no. 6, pp. 805-811, 2005.

[48] G. K. Ogilvie, "Recent advances in the treatment of vaccineassociated sarcomas," Veterinary Clinics of North AmericaSmall Animal Practice, vol. 31, no. 3, pp. 525-533, 2001.

[49] B. Séguin, "Feline injection site sarcomas," Veterinary Clinics of North America, vol. 32, no. 4, pp. 983-995, 2002.

[50] H. W. Chang, S. Y. Ho, H. F. Lo et al., "Vaccine-associated rhabdomyosarcoma with spinal epidural invasion and pulmonary metastasis in a cat," Veterinary Pathology, vol. 43, no. 1, pp. 55-58, 2006.

[51] T. J. Gruifydd Jones and A. H. Sparkes, "Vaccination and fibrosarcomas in cats," Veterinary Record, vol. 134, no. 12, p. 310, 1994.

[52] B. R. Madewell, T. L. Gieger, P. A. Pesavento, and M. S. Kent, "Vaccine site-associated sarcoma and malignant lymphoma in cats: a report of six cases (1997-2002)," Journal of the American Animal Hospital Association, vol. 40, no. 1, pp. 4750, 2004.

[53] M. J. Brearley, "Vaccine-associated feline sarcoma-an emerging problem," Journal of feline medicine and surgery, vol. 1, no. 1, pp. 5-6, 1999.

[54] M. Martin, "Vaccine-associated fibrosarcoma in a cat," Canadian Veterinary Journal, vol. 44, no. 8, pp. 660-663, 2003.

[55] J. P. Sauvage, "Vaccine-associated feline sarcoma," Veterinary Record, vol. 152, no. 17, p. 542, 2003.

[56] R. R. Dubielzig, K. L. Hawkins, and P. E. Miller, "Myofibroblastic sarcoma originating at the site of rabies vaccination in a cat," Journal of Veterinary Diagnostic Investigation, vol. 5, no. 4, pp. 637-638, 1993.

[57] D. G. Esplin, L. D. McGill, A. C. Meininger, and S. R. Wilson, "Postvaccination sarcomas in cats," Journal of the American Veterinary Medical Association, vol. 202, no. 8, pp. 12451247, 1993. 
[58] D. G. Esplin, M. H. Jaffe, and L. D. McGill, "Metastasizing liposarcoma associated with a vaccination site in a cat," Feline Practice, vol. 24, no. 5, pp. 20-23, 1996.

[59] C. Giudice, D. Stefanello, M. Sala et al., "Feline injection-site sarcoma: recurrence, tumour grading and surgical margin status evaluated using the three-dimensional histological technique," Veterinary Journal, vol. 186, no. 1, pp. 84-88, 2010.

[60] S. F. Grace, "Sarcomas, injection site," in The Feline Patient, G. D. Norsworthy, S. F. Grace, and L. P. Tilley, Eds., pp. 294 295, Blackwell, Oxford, UK, 3rd edition, 2006.

[61] K. Kamenica, T. Brill, J. Hirschberger, R. Köstlin, and W. Hermanns, "Vaccine-associated feline fibrosarcomas: histopathological findings and prognosisVakzineassoziierte feline fibrosarkome: histopathologische befunde und prognose," Tierärztliche Praxis Ausgabe K, vol. 36, no. 2, pp. 127-134, 2008.

[62] T. Kobayashi, M. L. Hauck, R. Dodge et al., "Preoperative radiotherapy for vaccine associated sarcoma in 92 cats," Veterinary Radiology and Ultrasound, vol. 43, no. 5, pp. 473479, 2002.

[63] S. North and T. Banks, "Sarcomas of the skin and subcutaneous tissues," in Small Animal Oncology. An Introduction, pp. 197-208, Saunders Elsevier, London, UK,, 2009.

[64] V. J. Poirier, D. H. Thamm, I. D. Kurzman et al., "Liposomeencapsulated doxorubicin (Doxil) and doxorubicin in the treatment of vaccine-associated sarcoma in cats," Journal of Veterinary Internal Medicine, vol. 16, no. 6, pp. 726-731, 2002.

[65] A. E. Hershey, K. U. Sorenmo, M. J. Hendrick, F. S. Shofer, and D. M. Vail, "Prognosis for presumed feline vaccineassociated sarcoma after excision: 61 cases (1986-1996)," Journal of the American Veterinary Medical Association, vol. 216, no. 1, pp. 58-61, 2000.

[66] M. J. Coyne, N. C. P. Reeves, and D. K. Rosen, "Estimated prevalence of injection-site sarcomas in cats during 1992," Journal of the American Veterinary Medical Association, vol. 210, no. 2, pp. 249-251, 1997.

[67] G. M. Gobar and P. H. Kass, "World Wide Web-based survey of vaccination practices, postvaccinal reactions, and vaccine site-associated sarcomas in cats," Journal of the American Veterinary Medical Association, vol. 220, no. 10, pp. 14771482, 2002.

[68] S. Lester, T. Clemett, and A. Burt, "Vaccine site-associated sarcomas in cats: clinical experience and a laboratory review (1982-1993)," Journal of the American Animal Hospital Association, vol. 32, no. 2, pp. 91-95, 1996.

[69] B. Tennant, "Feline injection-site fibrosarcomas: results of a BSAVA survey," Journal of Small Animal Practice, vol. 41, no. 4, pp. 181-182, 2000.

[70] M. J. Hendrick, "Historical review and current knowledge of risk factors involved in feline vaccine-associated sarcomas," Journal of the American Veterinary Medical Association, vol. 213, no. 10, pp. 1422-1423, 1998.

[71] M. J. Hendrick, "Feline vaccine-associated sarcomas: current studies on pathogenesis," Journal of the American Veterinary Medical Association, vol. 213, no. 10, pp. 1425-1426, 1998.

[72] M. J. Hendrick, F. S. Shofer, M. H. Goldschmidt et al., "Comparison of fibrosarcomas that developed at vaccination sites and at nonvaccination sites in cats: 239 cases (1991-1992)," Journal of the American Veterinary Medical Association, vol. 205, no. 10, pp. 1425-1429, 1994.
[73] L. P. Thornburg, "Postvaccination sarcomas in cats," Journal of the American Veterinary Medical Association, vol. 203, no. 2, pp. 193-196, 1993.

[74] P. H. Kass, W. L. Spangler, M. J. Hendrick et al., "Multicenter case-control study of risk factors associated with development of vaccine-associated sarcomas in cats," Journal of the American Veterinary Medical Association, vol. 223, no. 9, pp. 1283-1292, 2003.

[75] D. W. Macy and C. Guillermo Couto, "Prevention and treatment of injection-site sarcomas," Journal of Feline Medicine and Surgery, vol. 3, no. 4, pp. 169-170, 2001.

[76] M. C. McEntee and R. L. Page, "Feline vaccine-associated sarcomas," Journal of Veterinary Internal Medicine, vol. 15, no. 3, pp. 176-182, 2001.

[77] W. B. Morrison and R. M. Starr, "Vaccine-associated feline sarcomas," Journal of the American Veterinary Medical Association, vol. 218, no. 5, pp. 697-702, 2001.

[78] R. M. Gaskell, G. Gettinby, S. J. Graham, and D. Skilton, "Veterinary Products Committee working group report on feline and canine vaccination," Veterinary Record, vol. 150, no. 5, pp. 126-134, 2002.

[79] M. Hauck, "Feline injection site sarcomas," Veterinary Clinics of North America-Small Animal Practice, vol. 33, no. 3, pp. 553-571, 2003.

[80] H. Tjälve, "Adverse reactions to veterinary drugs in Sweden during 2002, part 3," Svensk Veterinärtidning, no. 11, pp. 3136, 2003.

[81] H. Tjälve, "Adverse reactions to veterinary drugs in Sweden during 2003, part 2," Svensk Veterinärtidning, no. 14, pp. 1725, 2004.

[82] J. R. Richards, R. M. Starr, H. E. Childers et al., "The current understanding and management of vaccine-associated sarcomas in cats," Journal of the American Veterinary Medical Association, vol. 226, no. 11, pp. 1821-1842, 2005.

[83] A. K. Gray and S. Knivett, "Suspected adverse reactions, 2001," Veterinary Record, vol. 151, no. 25, pp. 749-752, 2002.

[84] A. K. Gray, S. Knivett, C. Evans, and C. Long, "Suspected adverse reactions, 2002," Veterinary Record, vol. 153, no. 9, pp. 251-254, 2003.

[85] F. Dyer, R. Mulugeta, C. Evans, and A. Tait, "Suspected adverse reactions, 2003," Veterinary Record, vol. 154, no. 26, pp. 806-808, 2004.

[86] F. Dyer, R. Mulugeta, M. Spagnuolo-Weaver, and A. Tait, "Suspected adverse reactions, 2004," Veterinary Record, vol. 156, no. 18, pp. 561-563, 2005.

[87] F. Dyer, M. Spagnuolo-Weaver, and A. Tait, "Suspected adverse reactions, 2005," Veterinary Record, vol. 158, no. 14, pp. 464-466, 2006.

[88] F. Dyer, M. Spagnuolo-Weaver, S. Cooles, and A. Tait, "Suspected adverse reactions, 2006," Veterinary Record, vol. 160, no. 22, pp. 748-750, 2007.

[89] F. Dyer, M. Spagnuolo-Weaver, S. Cooles, and A. Tait, "Suspected adverse reactions, 2007," Veterinary Record, vol. 163, no. 3, pp. 69-72, 2008.

[90] F. Dyer, E. Brown, S. Cooles, and A. Tait, "Suspected adverse reactions, 2008," Veterinary Record, vol. 165, no. 6, pp. 162164, 2009.

[91] F. Dyer, G. Diesel, S. Cooles, and A. Tait, "Suspected adverse reactions, 2009," The Veterinary Record, vol. 167, no. 4, pp. 118-121, 2010.

[92] Z. Deim, N. Pálmai, and G. Cserni, "Feline vaccineassociated fibrosarcoma induced by aluminium compound in two cats: short communication," Acta Veterinaria Hungarica, vol. 56, no. 1, pp. 111-116, 2008. 
[93] B. A. Kidney, J. A. Ellis, D. M. Haines, and M. L. Jackson, "Evaluation of formalin-fixed paraffin-embedded tissues obtained from vaccine site-associated sarcomas of cats for DNA of feline immunodeficiency virus," American Journal of Veterinary Research, vol. 61, no. 9, pp. 1037-1041, 2000.

[94] P. Grasso and L. Golberg, "Early changes at the site of repeated subcutaneous injection of food colourings," Food and Cosmetics Toxicology, vol. 4, pp. 269-282, 1966.

[95] E. Boyland, R. L. Carter, J. W. Gorrod, and F. J. C. Roe, "Carcinogenic properties of certain rubber additives," European Journal of Cancer, vol. 4, no. 2, pp. 233-239, 1968.

[96] A. Braun and V. Kren, "Attempt to induce tumours by subcutaneous and intraperitoneal administration of Ferridextran (Spofa)," Neoplasma, vol. 15, no. 1, pp. 21-27, 1968.

[97] R. L. Carter, "Early development of injection-site sarcomas in rats: a study of tumours induced by a rubber additive," British Journal of Cancer, vol. 23, no. 2, pp. 408-416, 1969.

[98] R. L. Carter, B. C. Mitchley, and F. J. Roe, "Induction of tumours in mice and rats with ferric sodium gluconate and iron dextran glycerol glycoside," British Journal of Cancer, vol. 22, no. 3, pp. 521-526, 1968.

[99] P. Constantinides and M. Harkey, "Initiation of a transplantable fibrosarcoma by the synergism of two noninitiators, alpha-tocopherol and soya oil," Virchows Archiv, vol. 405, no. 3, pp. 285-297, 1985.

[100] J. Driessens, A. Clay, J. Vanlerenberghe, A. Dupont, L. Adenis, and A. Demaille, "Sarcomas at the subcutaneous injection site with trypan blue in the Wistar rat. Histological and cytological studies," Bulletin de l'Association Française pour l'Étude du Cancer, vol. 50, pp. 195-202, 1963.

[101] P. Grasso, S. D. Gangolli, and J. Hooson, "Connective tissue response to a short-term series of subcutaneous injections of sorbic acid or aflatoxin. Physico-chemical factors determining reaction to sorbic acid," British Journal of Cancer, vol. 23, no. 4, pp. 787-799, 1969.

[102] W. C. Huepner, "Experimental carcinogenic studies in macromolecular chemicals. 1. Neoplastic reactions in rats and mice after parenteral introduction of polyvinyl pyrrolidones," Cancer, vol. 10, no. 1, pp. 8-18, 1957.

[103] J. Hooson, P. Grasso, and S. D. Gangolli, "Early reactions of the subcutaneous tissue to repeated injections of carcinogens in aqueous solutions," British Journal of Cancer, vol. 25, no. 3, pp. 505-515, 1971.

[104] J. Hooson, P. Grasso, and S. D. Gangolli, "Injection site tumours and preceding pathological changes in rats treated subcutaneously with surfactants and carcinogens," British Journal of Cancer, vol. 27, no. 3, pp. 230-244, 1973.

[105] M. Matsuyama and K. Suzumori, "Effects of repeated subcutaneous injection of Tween-80 in rats," Nagoya Medical Journal, vol. 12, no. 1, pp. 1-7, 1966.

[106] Y. Nitta, K. Kamiya, M. Tanimoto, S. Sadamoto, O. Niwa, and K. Yokoro, "Induction of transplantable tumors by repeated subcutaneous injections of natural and synthetic vitamin E in mice and rats," Japanese Journal of Cancer Research, vol. 82, no. 5, pp. 511-517, 1991.

[107] S. D. Gangolli, P. Grasso, and L. Golberg, "Physical factors determining the early local tissue reactions produced by food colourings and other compounds injected subcutaneously," Food and Cosmetics Toxicology, vol. 5, no. 5, pp. 601-621, 1967.

[108] P. Grasso, S. D. Gangolli, L. Golberg, and J. Hooson, "Physicochemical and other factors determining local sarcoma production by food additives," Food and Cosmetics Toxicology, vol. 9, no. 4, pp. 463-IN1, 1971.
[109] P. Grasso, M. Sharratt, and A. J. Cohen, "Role of persistent, non-genotoxic tissue damage in rodent cancer and relevance to humans," Annual Review of Pharmacology and Toxicology, vol. 31, pp. 253-287, 1991.

[110] P. Grasso and R. F. Crampton, "The value of the mouse in carcinogenicity testing," Food and Cosmetics Toxicology, vol. 10, no. 3, pp. 418-426, 1972.

[111] J. B. Blumberg, P. C. Griffith, and K. A. Merendino, "The effect of specific compression on soft-tissue response to formalinized polyvinyl alcohol (ivalon) sponge: a critical evaluation," Annals of surgery, vol. 151, pp. 409-418, 1960.

[112] L. C. Buoen, I. Brand, and K. G. Brand, "Foreign body tumorigenesis: in vitro isolation and expansion of preneoplastic clonal cell populations," Journal of the National Cancer Institute, vol. 55, no. 3, pp. 721-723, 1975.

[113] K. G. Brand, "Diversity and complexity of carcinogenic processes: conceptual inferences from foreign body tumorigenesis," Journal of the National Cancer Institute, vol. 57, no. 5, pp. 973-976, 1976.

[114] K. G. Brand, L. C. Buoen, and I. Brand, "Foreign body tumorigenesis: timing and location of preneoplastic events," Journal of the National Cancer Institute, vol. 47, no. 4, pp. 829-836, 1971.

[115] K. G. Brand, L. C. Buoen, and I. Brand, "Foreign body tumorigenesis in mice: most probable number or originator cells," Journal of the National Cancer Institute, vol. 51, no. 3, pp. 1071-1074, 1973.

[116] K. G. Brand, L. C. Buoen, and I. Brand, "Foreign body tumorigenesis induced by glass and smooth and rough plastic: comparative study of preneoplastic events," Journal of the National Cancer Institute, vol. 55, no. 2, pp. 319-322, 1975.

[117] K. G. Brand, L. C. Buoen, K. H. Johnson, and I. Brand, "Etiological factors, stages, and the role of the foreign body in foreign body tumorigenesis: a review," Cancer Research, vol. 35, no. 2, pp. 279-286, 1975.

[118] K. G. Brand, L. C. Buoen, and I. Brand, "Foreign body tumorigenesis by vinyl chloride vinyl acetate copolymer: no evidence for chemical cocarcinogenesis," Journal of the National Cancer Institute, vol. 54, no. 5, pp. 1259-1262, 1975.

[119] L. C. Buoen, I. Brand, and K. G. Brand, "Foreign body tumorigenesis: in vitro isolation and expansion of preneoplastic clonal cell populations," Journal of the National Cancer Institute, vol. 55, no. 3, pp. 721-723, 1975.

[120] K. G. Brand, L. C. Buoen, and I. Brand, "Multiphasic incidence of foreign body induced sarcomas," Cancer Research, vol. 36, no. 10, pp. 3681-3683, 1976.

[121] P. A. Dewan, A. J. Owen, and R. W. Byard, "Long-term histological response to subcutaneously injected Polytef and Bioplastique in a rat model," British Journal of Urology, vol. 76, no. 2, pp. 161-164, 1995.

[122] M. M. Iomhair and S. M. Lavelle, "Effect of film size on production of foreign body sarcoma by perforated film implants," Technology and Health Care, vol. 5, no. 4, pp. 331334, 1997.

[123] K. H. Johnson, H. K. G. Ghobrial, and L. C. Buoen, "Nonfibroblastic origin of foreign body sarcomas implicated by histological and electron microscopic studies," Cancer Research, vol. 33, no. 12, pp. 3139-3154, 1973.

[124] K. H. Johnson, H. K. G. Ghobrial, L. C. Buoen, I. Brand, and K. G. Brand, "Intracisternal type A particles occurring in foreign body induced sarcomas," Cancer Research, vol. 33, no. 6, pp. 1165-1168, 1973. 
[125] R. D. Karp, K. H. Johnson, L. C. Buoen, K. G. Ghobrial, I. Brand, and K. G. Brand, "Tumorigenesis by millipore filters in mice: histology and ultrastructure of tissue reactions as related to pore size," Journal of the National Cancer Institute, vol. 51, no. 4, pp. 1275-1285, 1973.

[126] T. G. Moľzhess, "Carcinogenesis induced by foreign bodies," Biochemistry (Moscow), vol. 73, no. 7, pp. 763-775, 2008.

[127] F. Okada, M. Hosokawa, J. I. Hamada et al., "Progression of a weakly tumorigenic mouse fibrosarcoma at the site of early phase of inflammation caused by plastic plates," Japanese Journal of Cancer Research, vol. 84, no. 12, pp. 1230-1236, 1993.

[128] B. S. Oppenheimer, E. T. Oppenheimer, and A. P. Stout, "Sarcomas induced in rodents by imbedding various plastic films," Proceedings of the Society for Experimental Biology and Medicine, vol. 79, no. 3, pp. 366-369, 1952.

[129] B. S. Oppenheimer, E. T. Oppenheimer, A. P. Stout, and I. Danishefsky, "Malignant tumors resulting from embedding plastics in rodents," Science, vol. 118, no. 3063, pp. 305-306, 1953.

[130] B. S. Oppenheimer, E. T. Oppenheimer, and A. P. Stout, "Carcinogenicity effect of imbedding various plastic films in rats and mice," Surgical Forum, vol. 4, pp. 672-676, 1953.

[131] E. T. Oppenheimer, M. Willhite, A. P. Stout, I. Danishefsky, and M. M. Fishman, "A comparative study of the effects of imbedding Cellophane and polystyrene films in rats," Cancer Research, vol. 24, pp. 379-382, 1964.

[132] M. J. Thomassen, L. C. Bouen, and K. G. Brand, "Foreign body tumorigenesis: number, distribution, and cell density of preneoplastic clones," Journal of the National Cancer Institute, vol. 54, no. 1, pp. 203-207, 1975.

[133] L. Tomatis, "Studies in subcutaneous carcinogenesis with implants of glass and Teflon in mice," Acta-Unio Internationalis Contra Cancrum, vol. 19, pp. 607-611, 1963.

[134] F. C. Turner, "Sarcomas at sites of subcutaneously implanted Bakelite disks in rats," Journal of the National Cancer Institute, vol. 2, no. 8, pp. 81-83, 1941.

[135] T. Blankenstein and Z. Qin, "Chemical carcinogens as foreign bodies and some pitfalls regarding cancer immune surveillance," Advances in Cancer Research, vol. 90, pp. 179207, 2003.

[136] F. Okada, "Beyond foreign-body-induced carcinogenesis: impact of reactive oxygen species derived from inflammatory cells in tumorigenic conversion and tumor progression," International Journal of Cancer, vol. 121, no. 11, pp. 23642372, 2007.

[137] R. M. Peek and J. E. Crabtree, "Helicobacter infection and gastric neoplasia," Journal of Pathology, vol. 208, no. 2, pp. 233-248, 2006.

[138] D. L. Coleman, R. N. King, and J. D. Andrade, "The foreign body reaction: a chronic inflammatory response," Journal of Biomedical Materials Research, vol. 8, no. 5, pp. 199-211, 1974.

[139] C. J. Powell and C. L. Berry, "Non-genotoxic or epigenetic carcinogenesis," in General and Applied Toxicology, B. Ballantyne, T. Marrs, and T. Syversen, Eds., pp. 1757-1778, Macmillan Reference, Basingstoke, UK, 3rd edition, 2009.

[140] K. G. Brand, "Do implanted medical devices cause cancer?" Journal of Biomaterials Applications, vol. 8, no. 4, pp. 325343, 1994.

[141] J. P. Fryzek, L. Mellemkjaer, J. K. McLaughlin, W. J. Blot, and J. H. Olsen, "Cancer risk among patients with finger and hand joint and temporo- mandibular joint prostheses in
Denmark," International Journal of Cancer, vol. 81, no. 5, pp. 723-725, 1999.

[142] W. J. Gillespie, C. M. A. Frampton, R. J. Henderson, and P. M. Ryan, "The incidence of cancer following total hip replacement," Journal of Bone and Joint Surgery-Series B, vol. 70, no. 4, pp. 539-542, 1988.

[143] W. J. Gillespie, D. A. Henry, D. L. O'Connell et al., "Development of hematopoietic cancers after implantation of total joint replacement," Clinical Orthopaedics and Related Research, no. 329, supplement, pp. S290-S296, 1996.

[144] International Agency for Research on Cancer, Surgical Implants and Other Foreign Bodies. Summary of Data Reported and Evaluation, IARC, World Health Organisation, Geneva, Switzerland, 1999.

[145] S. Lewold, H. Olsson, P. Gustafson, A. Rydholm, and L. Lidgren, "Overall cancer incidence not increased after prosthetic knee replacement: 14,551 patients followed for 66,622 person-years," International Journal of Cancer, vol. 68, no. 1, pp. 30-33, 1996.

[146] E. B. Mathiesen, A. Ahlbom, G. Bermann, and J. U. Lindgren, "Total hip replacement and cancer. A cohort study," Journal of Bone and Joint Surgery - Series B, vol. 77, no. 3, pp. 345-350, 1995.

[147] D. B. McGregor, R. A. Baan, C. Partensky, J. M. Rice, and J. D. Wilbourn, "Evaluation of the carcinogenic risks to humans associated with surgical implants and other foreign bodiesa report of an IARC Monographs Programme Meeting," European Journal of Cancer, vol. 36, no. 3, pp. 307-313, 2000.

[148] J. H. Olsen, J. K. McLaughlin, O. Nyrén et al., "Hip and knee implantations among patients with osteoarthritis and risk of cancer: a record-linkage study from Denmark," International Journal of Cancer, vol. 81, no. 5, pp. 719-722, 1999.

[149] P. Paavolainen, E. Pukkala, P. Pulkkinen, and T. Visuri, "Cancer incidence in Finnish hip replacement patients from 1980 to 1995: a nationwide cohort study involving 31,651 patients," Journal of Arthroplasty, vol. 14, no. 3, pp. 272-280, 1999.

[150] T. Visuri, E. Pukkala, P. Paavolainen, P. Pulkkinen, and E. B. Riska, "Cancer risk after metal on metal and polyethylene on metal total hip arthroplasty," Clinical Orthopaedics and Related Research, no. 329, supplement, pp. S280-S289, 1996.

[151] O. Ben-Izhak, E. Vlodavsky, A. Ofer, A. Engel, S. Nitecky, and A. Hoffman, "Epithelioid angiosarcoma associated with a Dacron vascular graft," American Journal of Surgical Pathology, vol. 23, no. 11, pp. 1418-1422, 1999.

[152] W. A. Burns, S. Kanhouwa, L. Tillman, N. Saini, and J. B. Herrmann, "Fibrosarcoma occurring at the site of a plastic vascular graft," Cancer, vol. 29, no. 1, pp. 66-72, 1972.

[153] R. W. Morgan and M. Elcock, "Artificial implants and soft tissue sarcomas," Journal of Clinical Epidemiology, vol. 48, no. 4, pp. 545-549, 1995.

[154] L. Dubeau and R. S. Fraser, "Long-term effects of pulmonary shrapnel injury. Report of a case with carcinoma and residual shrapnel tract," Archives of Pathology and Laboratory Medicine, vol. 108, no. 5, pp. 407-409, 1984.

[155] G. Lindeman, M. J. McKay, K. L. Taubman, and A. M. Bilous, "Malignant fibrous histiocytoma developing in bone 44 years after shrapnel trauma," Cancer, vol. 66, no. 10, pp. 22292232, 1990.

[156] T. Teltzrow, C. Hallermann, S. Müller, and V. Schwipper, "Foreign body-induced angiosarcoma 60 years after a shellsplinter injury," Mund-Kiefer-und Gesichtschirurgie, vol. 10, no. 6, pp. 415-418, 2006. 
[157] J. Ceulemans, I. De Wever, R. Sciot, M. Debiec-Rychter, and A. T. Van Oosterom, "A sarcoma at the site of previous extravasation of adriamycin," Sarcoma, vol. 6, no. 4, pp. 135139, 2002.

[158] S. D. Deodhar, A. G. Kuklinca, D. G. Vidt, A. L. Robertson, and J. B. Hazard, "Development of reticulum-cell sarcoma at the site of antilymphocyte globulin injection in a patient with renal transplant," The New England Journal of Medicine, vol. 280, no. 20, pp. 1104-1106, 1969.

[159] R. M. R. Hearn, C. J. Fleming, S. L. Edwards, and A. E. Evans, "Depot antipsychotic treatment as a cause of injection site cutaneous lymphoma," British Journal of Dermatology, vol. 159, supplement 1, p. 92, 2008.

[160] A. Krivitzky, M. Bentata-Pessayre, F. Lejeune, P. Callard, G. Champault, and G. Delzant, "Malignant lymphoma initially of the buttocks: possible role of repeated intramuscular injections," Annales de Médicine Interne, vol. 135, no. 3, pp. 205-207, 1984.

[161] J. H. Lee, W. J. Griffiths, and R. H. Bottomley, "Extraosseous osteogenic sarcoma following an intramuscular injection," Cancer, vol. 40, no. 6, pp. 3097-3101, 1977.

[162] M. Mayrink, A. C. Mendonça, and P. R. Da Costa, "Softtissue sarcoma arising from a tissue necrosis caused by an intramuscular injection of diclofenac," Plastic and Reconstructive Surgery, vol. 112, no. 7, pp. 1970-1971, 2003.

[163] J. Romanos, E. Gontikakis, G. Scoretsanitis, and D. Tsiftsis, "Recurrent giant granuloma of the buttock after intramuscular injection," European Journal of Surgery, vol. 160, no. 11, pp. 643-644, 1994.

[164] K. Weinbren, R. Salm, and G. Greenberg, "Intramuscular injections of iron compounds and oncogenesis in man," British Medical Journal, vol. 1, no. 6114, pp. 683-685, 1978.

[165] E. Eisenbud and R. M. Walter, "Cancer at insulin injection site," Journal of the American Medical Association, vol. 233, no. 9, p. 985, 1975.

[166] J. Fielding, "Does sarcoma occur in man after intramuscular iron?" Scandinavian Journal of Haematology, vol. 19, supplement 32, pp. 100-104, 1977.

[167] M. B. McIllmurray and M. J. S. Langman, "Soft tissue sarcomas and intramuscular injections: an epidemiological survey," British Medical Journal, vol. 2, no. 6141, pp. 864-865, 1978.

[168] G. Mutwiri, V. Gerdts, M. Lopez, and L. A. Babiuk, "Innate immunity and new adjuvants," OIE Revue Scientifique et Technique, vol. 26, no. 1, pp. 147-156, 2007.

[169] V. E. J. C. Schijns and W. G. J. Degen, "Vaccine immunopotentiators of the future," Clinical Pharmacology and Therapeutics, vol. 82, no. 6, pp. 750-755, 2007.

[170] A. R. Spickler and J. A. Roth, "Adjuvants in veterinary vaccines: modes of action and adverse effects," Journal of Veterinary Internal Medicine, vol. 17, no. 3, pp. 273-281, 2003.

[171] P. G. H. Jones, G. Cowan, M. Gravendyck, T. Nagata, S. Robinson, and M. Waits, "Regulatory requirements for vaccine authorisation," OIE Revue Scientifique et Technique, vol. 26, no. 2, pp. 379-393, 2007.

[172] A. Lee, "Registration and regulation in the EC," in Vaccines for Veterinary Applications, A. R. Peters, Ed., pp. 307-319, Butterworth Heinemann, Oxford, UK, 1993.

[173] M. J. Day, "Vaccine side effects: fact and fiction," Veterinary Microbiology, vol. 117, no. 1, pp. 51-58, 2006.

[174] M. J. Day, "Vaccine safety in the neonatal period," Journal of Comparative Pathology, vol. 137, no. 1, pp. S51-S56, 2007.
[175] S. S. Ellenberg and M. M. Braun, "Monitoring the safety of vaccines: assessing the risks," Drug Safety, vol. 25, no. 3, pp. 145-152, 2002.

[176] E. K. Meyer, "Vaccine-associated adverse events," Veterinary Clinics of North America, vol. 31, no. 3, pp. 493-514, 2001.

[177] G. E. Moore, A. C. DeSantis-Kerr, L. F. Guptill, N. W. Glickman, H. B. Lewis, and L. T. Glickman, "Adverse events after vaccine administration in cats: 2,560 cases (2002-2005)," Journal of the American Veterinary Medical Association, vol. 231, no. 1, pp. 94-100, 2007.

[178] J. R. Patel and J. G. M. Heldens, "Review of companion animal viral diseases and immunoprophylaxis," Vaccine, vol. 27, no. 4, pp. 491-504, 2009.

[179] M. K. Daly, C. F. Saba, S. S. Crochik et al., "Fibrosarcoma adjacent to the site of microchip implantation in a cat," Journal of Feline Medicine and Surgery, vol. 10, no. 2, pp. 202205, 2008.

[180] P. Buracco, M. Martano, E. Morello, and A. Ratto, "Vaccineassociated-like fibrosarcoma at the site of a deep nonabsorbable suture in a cat," Veterinary Journal, vol. 163, no. 1, pp. 105-107, 2002.

[181] M. Vascellari, E. Melchiotti, M. A. Bozza, and F. Mutinelli, "Fibrosarcomas at presumed sites of injection in dogs: characteristics and comparison with non-vaccination site fibrosarcomas and feline post-vaccinal fibrosarcomas," Journal of Veterinary Medicine Series A, vol. 50, no. 6, pp. 286-291, 2003.

[182] M. Vascellari, F. Mutinelli, R. Cossettini, and E. Altinier, "Liposarcoma at the site of an implanted microchip in a dog," Veterinary Journal, vol. 168, no. 2, pp. 188-190, 2004.

[183] M. Vascellari, E. Melchiotti, and F. Mutinelli, "Fibrosarcoma with typical features of postinjection sarcoma at site of microchip implant in a dog: histologic and immunohistochemical study," Veterinary Pathology, vol. 43, no. 4, pp. 545548, 2006.

[184] S. Le Calvez, M.-F. Perron-Lepage, and R. Burnett, "Subcutaneous microchip-associated tumours in $\mathrm{B} 6 \mathrm{C} 3 \mathrm{~F} 1$ mice: a retrospective study to attempt to determine their histogenesis," Experimental and Toxicologic Pathology, vol. 57, no. 4, pp. 255-265, 2006.

[185] M. A. Miller, R. L. Aper, A. Fauber, W. E. Blevins, and J. A. Ramos-Vara, "Extraskeletal osteosarcoma associated with retained surgical sponge in a dog," Journal of Veterinary Diagnostic Investigation, vol. 18, no. 2, pp. 224-228, 2006.

[186] M. J. Hendrick, M. H. Goldschmidt, F. S. Shofer, Y. Y. Wang, and A. P. Somlyo, "Postvaccinal sarcomas in the cat: epidemiology and electron probe microanalytical identification of aluminum," Cancer Research, vol. 52, no. 19, pp. 5391-5394, 1992.

[187] S. J. James, M. Pogribna, B. J. Miller, B. Bolon, and L. Muskhelishvili, "Characterization of cellular response to silicone implants in rats: implications for foreign-body carcinogenesis," Biomaterials, vol. 18, no. 9, pp. 667-675, 1997.

[188] F. Balkwill and A. Mantovani, "Inflammation and cancer: back to Virchow?" The Lancet, vol. 357, no. 9255, pp. 539$545,2001$.

[189] S. Ballaz and J. L. Mulshine, "The potential contributions of chronic inflammation to lung carcinogenesis," Clinical Lung Cancer, vol. 5, no. 1, pp. 46-62, 2003.

[190] V. Guarino, M. D. Castellone, E. Avilla, and R. M. Melillo, "Thyroid cancer and inflammation," Molecular and Cellular Endocrinology, vol. 321, no. 1, pp. 94-102, 2010. 
[191] A. M. De Marzo, E. A. Platz, S. Sutcliffe et al., "Inflammation in prostate carcinogenesis," Nature Reviews Cancer, vol. 7, no. 4, pp. 256-269, 2007.

[192] E. A. Engels, "Inflammation in the development of lung cancer: epidemiological evidence," Expert Review of Anticancer Therapy, vol. 8, no. 4, pp. 605-615, 2008.

[193] M. C. Fantini and F. Pallone, "Cytokines: from gut inflammation to colorectal cancer," Current Drug Targets, vol. 9, no. 5, pp. 375-380, 2008.

[194] B. Farrow and B. M. Evers, "Inflammation and the development of pancreatic cancer," Surgical Oncology, vol. 10, no. 4, pp. 153-169, 2002.

[195] B. Goswami, M. Rajappa, M. Sharma, and A. Sharma, "Inflammation: its role and interplay in the development of cancer, with special focus on gynecological malignancies," International Journal of Gynecological Cancer, vol. 18, no. 4, pp. 591-599, 2008.

[196] J. B. Greer and D. C. Whitcomb, "Inflammation and pancreatic cancer: an evidence-based review," Current Opinion in Pharmacology, vol. 9, no. 4, pp. 411-418, 2009.

[197] G. Lee, T. C. Walser, and S. M. Dubinett, "Chronic inflammation, chronic obstructive pulmonary disease, and lung cancer," Current Opinion in Pulmonary Medicine, vol. 15, no. 4, pp. 303-307, 2009.

[198] C. J. McKay, P. Glen, and D. C. McMillan, "Chronic inflammation and pancreatic cancer," Best Practice and Research in Clinical Gastroenterology, vol. 22, no. 1, pp. 65-73, 2008.

[199] M. M. Moore, W. Chua, K. A. Charles, and S. J. Clarke, "Inflammation and cancer: causes and consequences," Clinical Pharmacology and Therapeutics, vol. 87, no. 4, pp. 504508, 2010.

[200] N. Azad, Y. Rojanasakul, and V. Vallyathan, "Inflammation and lung cancer: roles of reactive oxygen/nitrogen species," Journal of Toxicology and Environmental Health-Part B, vol. 11, no. 1, pp. 1-15, 2008.

[201] J. J. Salk, S. J. Salipante, R. A. Risques et al., "Clonal expansions in ulcerative colitis identify patients with neoplasia," Proceedings of the National Academy of Sciences of the United States of America, vol. 106, no. 49, pp. 20871-20876, 2009.

[202] P. Szlosarek, K. A. Charles, and F. R. Balkwill, "Tumour necrosis factor- $\alpha$ as a tumour promoter," European Journal of Cancer, vol. 42, no. 6, pp. 745-750, 2006.

[203] S. Vasto, G. Carruba, G. Candore, E. Italiano, D. Di Bona, and C. Caruso, "Inflammation and prostate cancer," Future Oncology, vol. 4, no. 5, pp. 637-645, 2008.

[204] G. Y. Yang, S. Taboada, and J. Liao, "Inflammatory bowel disease: a model of chronic inflammation-induced cancer," Methods in Molecular Biology (Clifton, N.J.), vol. 511, pp. 193-233, 2009.

[205] D. Assimakopoulos and G. Patrikakos, "The role of gastroesophageal reflux in the pathogenesis of laryngeal carcinoma," American Journal of Otolaryngology, vol. 23, no. 6, pp. 351$357,2002$.

[206] J. C. Cendan and K. E. Behrns, "Associated neoplastic disease in inflammatory Bowel disease," Surgical Clinics of North America, vol. 87, no. 3, pp. 659-672, 2007.

[207] L. A. Feagins, R. F. Souza, and S. J. Spechler, "Carcinogenesis in IBD: potential targets for the prevention of colorectal cancer," Nature Reviews Gastroenterology and Hepatology, vol. 6, no. 5, pp. 297-305, 2009.

[208] S. H. Itzkowitz and X. Yio, "Inflammation and cancer-IV. Colorectal cancer in inflammatory bowel disease: the role of inflammation," American Journal of Physiology, vol. 287, no. 1, pp. G7-G17, 2004.
[209] J. K. Triantafillidis, G. Nasioulas, and P. A. Kosmidis, "Colorectal cancer and inflammatory bowel disease: epidemiology, risk factors, mechanisms of carcinogenesis and prevention strategies," Anticancer Research, vol. 29, no. 7, pp. 27272737, 2009.

[210] C. D. M. Fletcher, "Soft tissue sarcomas apparently arising in chronic tropical ulcers," Histopathology, vol. 11, no. 5, pp. 501-510, 1987.

[211] D. S. Dolberg, R. Hollingsworth, M. Hertle, and M. J. Bissell, "Wounding and its role in RSV-mediated tumor formation," Science, vol. 230, no. 4726, pp. 676-678, 1985.

[212] E. Hormbrey, C. Han, A. Roberts, D. A. McGrouther, and A. L. Harris, "The relationship of human wound vascular endothelial growth factor (VEGF) after breast cancer surgery to circulating VEGF and angiogenesis," Clinical Cancer Research, vol. 9, no. 12, pp. 4332-4339, 2003.

[213] A. Kurtz, A. Aigner, R. H. Cabal-Manzano et al., "Differential regulation of a fibroblast growth factor-binding protein during skin carcinogenesis and wound healing," Neoplasia, vol. 6, no. 5, pp. 595-602, 2004.

[214] G. M. Marshall, L. Vanhamme, W. Y. Wong, H. Su, and P. K. Vogt, "Wounding acts as a tumor promoter in chickens inoculated with avian sarcoma virus 17," Virology, vol. 188, no. 1, pp. 373-377, 1992.

[215] M. Martins-Green and M. J. Bissell, "Localization of 9E3/ CEF-4 in avian tissues: expression is absent in Rous sarcoma virus-induced tumors but is stimulated by injury," Journal of Cell Biology, vol. 110, no. 3, pp. 581-595, 1990.

[216] M. Martins-Green, N. Boudreau, and M. J. Bissell, "Inflammation is responsible for the development of wound-induced tumors in chickens infected with Rous sarcoma virus," Cancer Research, vol. 54, no. 16, pp. 4334-4341, 1994.

[217] S. C. Robinson and L. M. Coussens, "Soluble mediators of inflammation during tumor development," Advances in Cancer Research, vol. 93, pp. 159-187, 2005.

[218] M. H. Sieweke, A. W. Stoker, and M. J. Bissell, "Evaluation of the cocarcinogenic effect of wounding in Rous sarcoma virus tumorigenesis," Cancer Research, vol. 49, no. 22, pp. 64196424, 1989.

[219] M. H. Sieweke, N. L. Thompson, M. B. Sporn, and M. J. Bissell, "Mediation of wound-related Rous sarcoma virus tumorigenesis by TGF- $\beta$," Science, vol. 248, no. 4963, pp. 1656-1660, 1990.

[220] H. G. R. Thompson, J. D. Mih, T. B. Krasieva, B. J. Tromberg, and S. C. George, "Epithelial-derived TGF- $\beta 2$ modulates basal and wound-healing subepithelial matrix homeostasis," American Journal of Physiology, vol. 291, no. 6, pp. L1277L1285, 2006.

[221] K. C. Flanders, "Smad3 as a mediator of the fibrotic response," International Journal of Experimental Pathology, vol. 85, no. 2, pp. 47-64, 2004.

[222] B. Kaminska, A. Wesolowska, and M. Danilkiewicz, "TGF beta signalling and its role in tumour pathogenesis," Acta Biochimica Polonica, vol. 52, no. 2, pp. 329-337, 2005.

[223] A. Mauviel, "Transforming growth factor-beta: a key mediator of fibrosis," Methods in Molecular Medicine, vol. 117, pp. 69-80, 2005.

[224] F. Verrechia and A. Mauviel, "Transforming growth factorbeta signalling through the Smad pathway: role in extracellular matrix gene expression and regulation," Journal of Investigative Dermatology, vol. 118, no. 2, pp. 211-215, 2002.

[225] P. R. Arany, K. C. Flanders, T. Kobayashi et al., "Smad3 deficiency alters key structural elements of the extracellular 
matrix and mechanotransduction of wound closure," Proceedings of the National Academy of Sciences of the United States of America, vol. 103, no. 24, pp. 9250-9255, 2006.

[226] G. S. Ashcroft, X. Yang, A. B. Glick et al., "Mice lacking Smad3 show accelerated wound healing and an impaired local inflammatory response," Nature Cell Biology, vol. 1, no. 5, pp. 260-266, 1999.

[227] F. R. Diez, A. A. Garrido, A. Sharma et al., "RasGRP1 transgenic mice develop cutaneous squamous cell carcinomas in response to skin wounding: potential role of granulocyte colony-stimulating factor," American Journal of Pathology, vol. 175, no. 1, pp. 392-399, 2009.

[228] S. O. P. Hofer, D. Shrayer, J. S. Reichner, H. J. Hoekstra, and H. J. Wanebo, "Wound-induced tumor progression: a probable role in recurrence after tumor resection," Archives of Surgery, vol. 133, no. 4, pp. 383-389, 1998.

[229] S. Inokuchi, T. Aoyama, K. Miura et al., "Disruption of TAK1 in hepatocytes causes hepatic injury, inflammation, fibrosis, and carcinogenesis," Proceedings of the National Academy of Sciences of the United States of America, vol. 107, no. 2, pp. 844-849, 2010.

[230] J. L. Sequeira, S. Kobayasi, and M. A. M. Rodrigues, "Early and late effects of wound healing on development of colon tumours in a model of colon carcinogenesis by 1,2dimethylhydrazine in the rat," Pathology, vol. 32, no. 4, pp. 250-252, 2000.

[231] C. H. Stuelten, A. Barbul, J. I. Busch et al., "Acute wounds accelerate tumorigenesis by a T cell-dependent mechanism," Cancer Research, vol. 68, no. 18, pp. 7278-7282, 2008.

[232] L. Weiss, "Some effects of mechanical trauma on the development of primary cancers and their metastases," Journal of Forensic Sciences, vol. 35, no. 3, pp. 614-627, 1990.

[233] J. Kluwe, A. Mencin, and R. F. Schwabe, "Toll-like receptors, wound healing, and carcinogenesis," Journal of Molecular Medicine, vol. 87, no. 2, pp. 125-138, 2009.

[234] S. Rakoff-Nahoum and R. Medzhitov, "Toll-like receptors and cancer," Nature Reviews Cancer, vol. 9, no. 1, pp. 57-63, 2009.

[235] H. Sarir, E. Mortaz, W. T. Janse, M. E. Givi, F. P. Nijkamp, and G. Folkerts, "IL-8 production by macrophages is synergistically enhanced when cigarette smoke is combined with TNF- $\alpha$," Biochemical Pharmacology, vol. 79, no. 5, pp. 698$705,2010$.

[236] R. Bedwani, E. Renganathan, F. El Kwhsky et al., "Schistosomiasis and the risk of bladder cancer in Alexandria, Egypt," British Journal of Cancer, vol. 77, no. 7, pp. 1186-1189, 1998.

[237] Y. Hirao, W. J. Kim, and K. Fujimoto, "Environmental factors promoting bladder cancer," Current Opinion in Urology, vol. 19, no. 5, pp. 494-499, 2009.

[238] International Agency for Research on Cancer, Evaluation of the Carcinogenic Risk to Humans. Schistosomes, Liver Flukes and Helicobacter pylori, IARC Monographs vol. 61, World Health Organisation, Geneva, Switzerland, 1994.

[239] G. Jatzko, R. Kleinert, and H. Denk, "Intestinal schistosomiasis, a facultative precancerous condition? Review of the literature with reference to Schistosoma japonicum associated rectum carcinoma," Chirurg, vol. 68, no. 7, pp. 727-731, 1997.

[240] D. A. Mayer and B. Fried, "The role of helminth infections in carcinogenesis," Advances in Parasitology, vol. 65, pp. 239296, 2007.

[241] D. S. Michaud, "Chronic inflammation and bladder cancer," Urologic Oncology, vol. 25, no. 3, pp. 260-268, 2007.
[242] M. H. Mostafa, S. A. Sheweita, and P. J. O'Connor, "Relationship between schistosomiasis and bladder cancer," Clinical Microbiology Reviews, vol. 12, no. 1, pp. 97-111, 1999.

[243] M. P. Rosin, W. A. Anwar, and A. J. Ward, "Inflammation, chromosomal instability, and cancer: the schistosomiasis model," Cancer Research, vol. 54, no. 7, supplement, pp. 1929s-1933s, 1994.

[244] A. Yosry, "Schistosomiasis and neoplasia," Contributions to Microbiology, vol. 13, pp. 81-100, 2006.

[245] N. Ramchurren, K. Cooper, and I. C. Summerhayes, "Molecular events underlying schistosomiasis-related bladder cancer," International Journal of Cancer, vol. 62, no. 3, pp. 237244, 1995.

[246] Y. Tamimi, P. P. Bringuier, F. Smit et al., "Homozygous deletions of p16(INK4) occur frequently in bilharziasisassociated bladder cancer," International Journal of Cancer, vol. 68, no. 2, pp. 183-187, 1996.

[247] B. J. Vennervald and K. Polman, "Helminths and malignancy," Parasite Immunology, vol. 31, no. 11, pp. 686-696, 2009.

[248] M. J. Blaser, G. I. Perez-Perez, H. Kleanthous et al., "Infection with Helicobacter pylori strains possessing cagA is associated with an increased risk of developing adenocarcinoma of the stomach," Cancer Research, vol. 55, no. 10, pp. 2111-2115, 1995.

[249] C. Chao and M. R. Hellmich, "Gastrin, inflammation, and carcinogenesis," Current Opinion in Endocrinology, Diabetes and Obesity, vol. 17, no. 1, pp. 33-39, 2010.

[250] A. Nomura, G. N. Stemmermann, P. H. Chyou, I. Kato, G. I. Perez-Perez, and M. J. Blaser, "Helicobacter pylori infection and gastric carcinoma among Japanese Americans in Hawaii," The New England Journal of Medicine, vol. 325, no. 16, pp. 1132-1136, 1991.

[251] J. Parsonnet, G. D. Friedman, D. P. Vandersteen et al., "Helicobacter pylori infection and the risk of gastric carcinoma," The New England Journal of Medicine, vol. 325, no. 16, pp. 1127-1131, 1991.

[252] P. Sipponen and H. Hyvärinen, "Role of Helicobacter pylori in the pathogenesis of gastritis, peptic ulcer and gastric cancer," Scandinavian Journal of Gastroenterology, Supplement, vol. 28, no. 196, supplement, pp. 3-6, 1993.

[253] C. Stoicov, R. Saffari, X. Cai, C. Hasyagar, and J. Houghton, "Molecular biology of gastric cancer: helicobacter infection and gastric adenocarcinoma: bacterial and host factors responsible for altered growth signaling," Gene, vol. 341, no. 1-2, pp. 1-17, 2004.

[254] S. E. Erdman, V. P. Rao, T. Poutahidis et al., "Nitric oxide and TNF- $\alpha$ trigger colonic inflammation and carcinogenesis in Helicobacter hepaticus-infected, Rag2-deficient mice," Proceedings of the National Academy of Sciences of the United States of America, vol. 106, no. 4, pp. 1027-1032, 2009.

[255] N. Yoshida, "Inflammation and oxidative stress in gastroesophageal reflux disease," Journal of Clinical Biochemistry and Nutrition, vol. 40, no. 1, pp. 13-23, 2007.

[256] S. M. Cohen, "Role of urinary physiology and chemistry in bladder carcinogenesis," Food and Chemical Toxicology, vol. 33, no. 9, pp. 715-730, 1995.

[257] S. M. Cohen, S. L. Johansson, L. L. Arnold, and T. A. Lawson, "Urinary tract calculi and thresholds in carcinogenesis," Food and Chemical Toxicology, vol. 40, no. 6, pp. 793-799, 2002.

[258] R. A. Crallan, N. T. Georgopoulos, and J. Southgate, "Experimental models of human bladder carcinogenesis," Carcinogenesis, vol. 27, no. 3, pp. 374-381, 2006. 
[259] M. A. Dominick, M. R. White, T. P. Sanderson et al., "Urothelial carcinogenesis in the urinary bladder of male rats treated with muraglitazar, a PPAR $\alpha / \gamma$ agonist: evidence for urolithiasis as the inciting event in the mode of action," Toxicologic Pathology, vol. 34, no. 7, pp. 903-920, 2006.

[260] M. Kaneko, K. Morimura, T. Nishikawa et al., "Different genetic alterations in rat forestomach tumors induced by genotoxic and non-genotoxic carcinogens," Carcinogenesis, vol. 23, no. 10, pp. 1729-1735, 2002.

[261] R. Kroes and P. W. Wester, "Forestomach carcinogens: possible mechanisms of action," Food and Chemical Toxicology, vol. 24, no. 10-11, pp. 1083-1089, 1986.

[262] H. Ogasawara, K. Imaida, H. Ishiwata et al., "Urinary bladder carcinogenesis induced by melamine in F344 male rats: correlation between carcinogenicity and urolith formation," Carcinogenesis, vol. 16, no. 11, pp. 2773-2777, 1995.

[263] M. A. Shibata, R. Hasegawa, M. Sano, T. Shirai, and S. Fukushima, "Timing effects of uracil-induced urolithiasis on amplification of second-stage promotion in rat bladder carcinogenesis," Japanese Journal of Cancer Research, vol. 82, no. 10, pp. 1077-1084, 1991.

[264] S. Tamano, M. Hirose, H. Tanaka, E. Asakawa, K. Ogawa, and N. Ito, "Forestomach neoplasm induction in F344/DuCrj rats and B6C3F mice exposed to sesamol," Japanese Journal of Cancer Research, vol. 83, no. 12, pp. 1279-1285, 1992.

[265] P. T. Wester and R. Kroes, "Forestomach carcinogens: pathology and relevance to man," Toxicologic Pathology, vol. 16, no. 2, pp. 165-171, 1988.

[266] J. A. Barter and J. H. Sherman, "An evaluation of the carcinogenic hazard of 1,4-dichlorobenzene based on internationally recognized criteria," Regulatory Toxicology and Pharmacology, vol. 29, no. 1, pp. 64-79, 1999.

[267] K. Blumbach, A. Pähler, H. M. Deger, and W. Dekant, "Biotransformation and male rat-specific renal toxicity of diethyl ethyl- and dimethyl methylphosphonate," Toxicological Sciences, vol. 53, no. 1, pp. 24-32, 2000.

[268] S. J. Borghoff, B. G. Short, and J. A. Swenberg, "Biochemical mechanisms and pathobioloby of $\alpha(2 \mathrm{u})$-globulin nephropathy," Annual Review of Pharmacology and Toxicology, vol. 30, pp. 349-367, 1990.

[269] D. R. Dietrich and J. A. Swenberg, "Renal carcinogenesis," in Toxicology of the Kidney, J. B. Hook and R. S. Goldstein, Eds., pp. 495-537, Raven Press, New York, NY, USA, 2nd edition, 1993.

[270] G. C. Hard, I. S. Rodgers, K. P. Baetcke, W. L. Richards, R. E. McGaughy, and L. R. Valcovic, "Hazard evaluation of chemicals that cause accumulation of $\alpha(2 \mathrm{u})$-globulin, hyaline droplet nephropathy, and tubule neoplasia in the kidneys of male rats," Environmental Health Perspectives, vol. 99, pp. 313-349, 1993.

[271] R. L. Kanerva, G. M. Ridder, L. C. Stone, and C. L. Alden, "Characterization of spontaneous and decalin-induced hyaline droplets in kidneys of adult male rats," Food and Chemical Toxicology, vol. 25, no. 1, pp. 63-82, 1987.

[272] L. D. Lehman-McKeeman, "Male rat-specific light hydrocarbon nephropathy," in Toxicology of the Kidney, J. B. Hook and R.S. Goldstein, Eds., pp. 477-494, Raven Press, New York, NY, USA, 2nd edition, 1993.

[273] X. Shi, V. Castranova, B. Halliwell, and V. Vallyathan, "Reactive oxygen species and silica-induced carcinogenesis," Journal of Toxicology and Environmental Health-Part B, vol. 1, no. 3, pp. 181-197, 1998.

[274] J. A. Svenberg, D. R. Dietrich, R. M. McClain, and S. M. Cohen, "Species-specific mechanisms of carcinogenesis," in
Mechanisms of Carcinogenesis in Risk Identification, H. Vainio, P. N. Magee, D. B. McGregor, and A. J. McMichael, Eds., pp. 477-500, International Agency for Research on Cancer, Geneva, Switzerland, 1992.

[275] S. D. Turner, H. Tinwell, W. Piegorsch, P. Schmezer, and J. Ashby, "The male rat carcinogens limonene and sodium saccharin are not mutagenic to male Big Blue ${ }^{\mathrm{TM}}$ rats," Mutagenesis, vol. 16, no. 4, pp. 329-332, 2001.

[276] N. Azad, Y. Rojanasakul, and V. Vallyathan, "Inflammation and lung cancer: roles of reactive oxygen/nitrogen species," Journal of Toxicology and Environmental Health-Part B, vol. 11, no. 1, pp. 1-15, 2008.

[277] M. Dougan and G. Dranoff, "Inciting inflammation: the RAGE about tumor promotion," Journal of Experimental Medicine, vol. 205, no. 2, pp. 267-270, 2008.

[278] A. Federico, F. Morgillo, C. Tuccillo, F. Ciardiello, and C. Loguercio, "Chronic inflammation and oxidative stress in human carcinogenesis," International Journal of Cancer, vol. 121, no. 11, pp. 2381-2386, 2007.

[279] T. O. Frommel and E. J. Zarling, "Chronic inflammation and cancer: potential role of Bcl-2 gene family members as regulators of cellular antioxidant status," Medical Hypotheses, vol. 52, no. 1, pp. 27-30, 1999.

[280] T. A. Gonda, S. Tu, and T. C. Wang, "Chronic inflammation, the tumor microenvironment and carcinogenesis," Cell Cycle, vol. 8, no. 13, pp. 2005-2013, 2009.

[281] J. E. Goodman, L. J. Hofseth, S. P. Hussain, and C. C. Harris, "Nitric oxide and p53 in cancer-prone chronic inflammation and oxyradical overload disease," Environmental and Molecular Mutagenesis, vol. 44, no. 1, pp. 3-9, 2004.

[282] N. Khansari, Y. Shakiba, and M. Mahmoudi, "Chronic inflammation and oxidative stress as a major cause of agerelated diseases and cancer," Recent Patents on Inflammation and Allergy Drug Discovery, vol. 3, no. 1, pp. 73-80, 2009.

[283] J. K. Kundu and Y. J. Surh, "Inflammation: gearing the journey to cancer," Mutation Research, vol. 659, no. 1-2, pp. 15-30, 2008.

[284] M. Macarthur, G. L. Hold, and E. M. El-Omar, "Inflammation and Cancer II. Role of chronic inflammation and cytokine gene polymorphisms in the pathogenesis of gastrointestinal malignancy," American Journal of Physiology, vol. 286, no. 4, pp. G515-G520, 2004.

[285] A. Mantovani, P. Allavena, A. Sica, and F. Balkwill, "Cancerrelated inflammation," Nature, vol. 454, no. 7203, pp. 436444, 2008.

[286] L. B. Meira, J. M. Bugni, S. L. Green et al., "DNA damage induced by chronic inflammation contributes to colon carcinogenesis in mice," Journal of Clinical Investigation, vol. 118, no. 7, pp. 2516-2525, 2008.

[287] S. F. Moss and M. J. Blaser, "Mechanisms of disease: inflammation and the origins of cancer," Nature Clinical Practice Oncology, vol. 2, no. 2, pp. 90-97, 2005.

[288] H. Ohshima, M. Tatemichi, and T. Sawa, "Chemical basis of inflammation-induced carcinogenesis," Archives of Biochemistry and Biophysics, vol. 417, no. 1, pp. 3-11, 2003.

[289] C. Porta, P. Larghi, M. Rimoldi et al., "Cellular and molecular pathways linking inflammation and cancer," Immunobiology, vol. 214, no. 9-10, pp. 761-777, 2009.

[290] E. Shacter and S. A. Weitzman, "Chronic inflammation and cancer," Oncology, vol. 16, no. 2, pp. 217-230, 2002.

[291] T. T. Tan and L. M. Coussens, "Humoral immunity, inflammation and cancer," Current Opinion in Immunology, vol. 19, no. 2, pp. 209-216, 2007. 
[292] R. Visconti and D. Grieco, "New insights on oxidative stress in cancer," Current Opinion in Drug Discovery and Development, vol. 12, no. 2, pp. 240-245, 2009.

[293] F. D’Acquisto, F. Maione, and M. Pederzoli-Ribeil, "From IL-15 to IL-33: the never-ending list of new players in inflammation. Is it time to forget the humble aspirin and move ahead?" Biochemical Pharmacology, vol. 79, no. 4, pp. 525-534, 2010.

[294] R. Katayama, M. K. Huelsmeyer, A. K. Marr, I. D. Kurzman, D. H. Thamm, and D. M. Vail, "Imatinib mesylate inhibits platelet-derived growth factor activity and increases chemosensitivity in feline vaccine-associated sarcoma," Cancer Chemotherapy and Pharmacology, vol. 54, no. 1, pp. 2533, 2004.

[295] S. Mocellin and D. Nitti, "TNF and cancer: the two sides of the coin," Frontiers in Bioscience, vol. 13, no. 7, pp. 27742783, 2008.

[296] R. A. Roberts and I. Kimber, "Cytokines in non-genotoxic hepatocarcinogenesis," Carcinogenesis, vol. 20, no. 8, pp. 1397-1401, 1999.

[297] R. A. Roberts, N. H. James, S. Cosulich, S. C. Hasmall, and G. Orphanides, "Role of cytokines in non-genotoxic hepatocarcinogenesis: cause or effect?" Toxicology Letters, vol. 120, no. 1-3, pp. 301-306, 2001.

[298] M. Schäfer and S. Werner, "Cancer as an overhealing wound: an old hypothesis revisited," Nature Reviews Molecular Cell Biology, vol. 9, no. 8, pp. 628-638, 2008.

[299] J. Scheller, N. Ohnesorge, and S. Rose-John, "Interleukin6 trans-signalling in chronic inflammation and cancer," Scandinavian Journal of Immunology, vol. 63, no. 5, pp. 321329, 2006.

[300] G. Sethi, B. Sung, and B. B. Aggarwal, “TNF: a master switch for inflammation to cancer," Frontiers in Bioscience, vol. 13, no. 13, pp. 5094-5107, 2008.

[301] D. Wang, R. N. DuBois, and A. Richmond, "The role of chemokines in intestinal inflammation and cancer," Current Opinion in Pharmacology, vol. 9, no. 6, pp. 688-696, 2009.

[302] S. J. Flavell, T. Z. Hou, S. Lax, A. D. Filer, M. Salmon, and C. D. Buckley, "Fibroblasts as novel therapeutic targets in chronic inflammation," British Journal of Pharmacology, vol. 153, no. 1, pp. S241-S246, 2008.

[303] J. A. Van Ginderachter, K. Movahedi, J. Van Den Bossche, and P. De Baetselier, "Macrophages, PPARs, and cancer," PPAR Research, vol. 2008, Article ID 169414, 2008.

[304] T. Lawrence and D. W. Gilroy, "Chronic inflammation: a failure of resolution?" International Journal of Experimental Pathology, vol. 88, no. 2, pp. 85-94, 2007.

[305] S. Rajput and A. Wilber, "Roles of inflammation in cancer initiation, progression, and metastasis," Frontiers in Bioscience, vol. 2, pp. 176-183, 2010.

[306] M. Quante and T. C. Wang, "Inflammation and stem cells in gastrointestinal carcinogenesis," Physiology, vol. 23, no. 6, pp. 350-359, 2008.

[307] B. J. Rollins, "Inflammatory chemokines in cancer growth and progression," European Journal of Cancer, vol. 42, no. 6, pp. 760-767, 2006.

[308] P. Hainaut, "The tumor suppressor protein p53: a receptor to genotoxic stress that controls cell growth and survival," Current Opinion in Oncology, vol. 7, no. 1, pp. 76-82, 1995.

[309] M. Ljungman and D. P. Lane, "Transcription-guarding the genome by sensing DNA damage," Nature Reviews Cancer, vol. 4, no. 9, pp. 727-737, 2004.
[310] C. Méplan, M. J. Richard, and P. Hainaut, "Redox signalling and transition metals in the control of the p53 pathway," Biochemical Pharmacology, vol. 59, no. 1, pp. 25-33, 2000.

[311] O. Pluquet and P. Hainaut, "Genotoxic and non-genotoxic pathways of p53 induction," Cancer Letters, vol. 174, no. 1, pp. 1-15, 2001.

[312] A. Quiñones and N. G. Rainov, "Identification of genotoxic stress in human cells by fluorescent monitoring of p53 expression," Mutation Research, vol. 494, no. 1-2, pp. 73-85, 2001.

[313] T. Andoh, "Signal transduction pathways leading to cell cycle arrest and apoptosis induced by DNA topoisomerase poisons," Cell Biochemistry and Biophysics, vol. 33, no. 2, pp. 181-188, 2000.

[314] S. C. Hasmall and R. A. Roberts, "The perturbation of apoptosis and mitosis by drugs and xenobiotics," Pharmacology and Therapeutics, vol. 82, no. 1, pp. 63-70, 1999.

[315] M. B. Kastan, C. E. Canman, and C. J. Leonard, "P53, cell cycle control and apoptosis: implications for cancer," Cancer and Metastasis Reviews, vol. 14, no. 1, pp. 3-15, 1995.

[316] E. Kim, A. Giese, and W. Deppert, "Wild-type p53 in cancer cells: when a guardian turns into a blackguard," Biochemical Pharmacology, vol. 77, no. 1, pp. 11-20, 2009.

[317] A. Mally and J. K. Chipman, "Non-genotoxic carcinogens: early effects on gap junctions, cell proliferation and apoptosis in the rat," Toxicology, vol. 180, no. 3, pp. 233-248, 2002.

[318] D. W. Meek, "P53 regulation and activity," Toxicology, vol. 240, no. 3, pp. 129-153, 2007.

[319] M. E. Perry and A. J. Levine, "Tumor-suppressor p53 and the cell cycle," Current Opinion in Genetics and Development, vol. 3, no. 1, pp. 50-54, 1993.

[320] K. J. L. Riley and L. J. Maher, "p53-RNA interactions: new clues in an old mystery," RNA, vol. 13, no. 11, pp. 1825-1833, 2007.

[321] R. A. Roberts, "Non-genotoxic hepatocarcinogenesis: suppression of apoptosis by peroxisome proliferators," Annals of the New York Academy of Sciences, vol. 804, pp. 588-611, 1996.

[322] F. Rodier, J. Campisi, and D. Bhaumik, "Two faces of p53: aging and tumor suppression," Nucleic Acids Research, vol. 35, no. 22, pp. 7475-7484, 2007.

[323] B. F. Trump, I. K. Berezesky, S. H. Chang, and P. C. Phelps, "The pathways of cell death: oncosis, apoptosis, and necrosis," Toxicologic Pathology, vol. 25, no. 1, pp. 82-88, 1997.

[324] K. H. Vousden, "Outcomes of p53 activation-spoilt for choice," Journal of Cell Science, vol. 119, no. 24, pp. 50155020, 2006.

[325] M. R. Alison and C. E. Sarraf, "Apoptosis: regulation and relevance to toxicology," Human and Experimental Toxicology, vol. 14, no. 3, pp. 234-247, 1995.

[326] J. T. Isaacs, "Role of programmed cell death in carcinogenesis," Environmental Health Perspectives, vol. 101, no. 5, supplement, pp. 27-33, 1993.

[327] O. Ndozangue-Touriguine, J. Hamelin, and J. Bréard, "Cytoskeleton and apoptosis," Biochemical Pharmacology, vol. 76, no. 1, pp. 11-18, 2008.

[328] A. H. Wyllie, "Apoptosis and carcinogenesis," European Journal of Cell Biology, vol. 73, no. 3, pp. 189-197, 1997.

[329] A. Benzinger, N. Muster, H. B. Koch, J. R. Yates, and H. Hermeking, "Targeted proteomic analysis of 14-3-3 $\sigma$, a p53 effector commonly silenced in cancer," Molecular and Cellular Proteomics, vol. 4, no. 6, pp. 785-795, 2005. 
[330] R. A. Buzzell, "Carcinogenesis of cutaneous malignancies," Dermatologic Surgery, vol. 22, no. 3, pp. 209-215, 1996.

[331] A. V. Gudkov and E. A. Komarova, "Dangerous habits of a security guard: the two faces of p53 as a drug target," Human Molecular Genetics, vol. 16, no. 1, pp. R67-R72, 2007.

[332] D. P. Guimaraes and P. Hainaut, "TP53: a key gene in human cancer," Biochimie, vol. 84, no. 1, pp. 83-93, 2002.

[333] A. Honda, R. Abe, Y. Yoshihisa et al., "Deficient deletion of apoptotic cells by macrophage migration inhibitory factor (MIF) overexpression accelerates photocarcinogenesis," Carcinogenesis, vol. 30, no. 9, pp. 1597-1605, 2009.

[334] J. E. Kucab, D. H. Phillips, and V. M. Arlt, "Linking environmental carcinogen exposure to TP53 mutations in human tumours using the human TP53 knock-in (Hupki) mouse model," FEBS Journal, vol. 277, no. 12, pp. 2567-2583, 2010.

[335] A. Petitjean, M. I. W. Achatz, A. L. Borresen-Dale, P. Hainaut, and M. Olivier, “TP53 mutations in human cancers: functional selection and impact on cancer prognosis and outcomes," Oncogene, vol. 26, no. 15, pp. 2157-2165, 2007.

[336] A. Petitjean, E. Mathe, S. Kato et al., "Impact of mutant p53 functional properties on TP53 mutation patterns and tumor phenotype: lessons from recent developments in the IARC TP53 database," Human Mutation, vol. 28, no. 6, pp. 622629, 2007.

[337] C. P. Rubbi and J. Milner, "P53: gatekeeper, caretaker or both?" in 25 Years of p53 Research, P. Hainaut and K. G. Wiman, Eds., pp. 233-253, Springer, London, UK, 2005.

[338] I. Silins, N. Finnberg, A. Ståhl, J. Högberg, and U. Stenius, "Reduced ATM kinase activity and an attenuated p53 response to DNA damage in carcinogen-induced preneoplastic hepatic lesions in the rat," Carcinogenesis, vol. 22, no. 12, pp. 2023-2031, 2001.

[339] T. Soussi and K. G. Wiman, "Shaping genetic alterations in human cancer: the p53 mutation paradigm," Cancer Cell, vol. 12, no. 4, pp. 303-312, 2007.

[340] C. Potten and J. Wilson, "The judge, the jury and the executioner-the genes that control cell death: p53-the guardian of the genome in embryos and adults," in Apoptosis. The Life and Death of Cells, pp. 91-114, Cambridge University Press, Cambridge, UK, 2004.

[341] B. Burnworth, S. Arendt, S. Muffler et al., "The multistep process of human skin carcinogenesis: a role for p53, cyclin D1, hTERT, p16, and TSP-1," European Journal of Cell Biology, vol. 86, no. 11-12, pp. 763-780, 2007.

[342] G. S. Buzard, "Studies of oncogene activation and tumor suppressor gene inactivation in normal and neoplastic rodent tissue," Mutation Research, vol. 365, no. 1-3, pp. 43-58, 1996.

[343] S. Chevalier and R. A. Roberts, "G1-arrested FaO cells reenter the cell cycle upon stimulation with the rodent nongenotoxic hepatocarcinogen nafenopin," Carcinogenesis, vol. 20, no. 7, pp. 1209-1213, 1999.

[344] J. J. Cohen, M. D. Devore, M. Cikara, and E. A. Dowling, "Cell death in immune, inflammatory and stress responses," in Essentials of Apoptosis. A Guide for Basic and Clinical Research, X.-M. Yin and Z. Dong, Eds., pp. 201-210, Humana Press, Totowa, NJ, USA, 2003.

[345] S. M. Cohen, "Cell proliferation and carcinogenesis," Drug Metabolism Reviews, vol. 30, no. 2, pp. 339-357, 1998.

[346] P. Correa and M. J. S. Miller, "Carcinogenesis, apoptosis and cell proliferation,” British Medical Bulletin, vol. 54, no. 1, pp. 151-162, 1998.

[347] P. J. Duerksen-Hughes, J. Yang, and O. Ozcan, "p53 induction as a genotoxic test for twenty-five chemicals undergoing in vivo carcinogenicity testing," Environmental Health Perspectives, vol. 107, no. 10, pp. 805-812, 1999.

[348] H. B. Jones, S. R. Eldridge, B. E. Butterworth, and J. R. Foster, "Measures of cell replication in risk/safety assessment of xenobiotic-induced, nongenotoxic carcinogenesis," Regulatory Toxicology and Pharmacology, vol. 23, no. 2, pp. 117127, 1996.

[349] J. C. Semenza and L. H. Weasel, "Molecular epidemiology in environmental health: the potential of tumor suppressor gene p53 as a biomarker," Environmental Health Perspectives, vol. 105, supplement 1, pp. 155-163, 1997.

[350] J. C. Neil, E. R. Cameron, and E. W. Baxter, "p53 and tumour viruses: catching the guardian off-guard," Trends in Microbiology, vol. 5, no. 3, pp. 115-120, 1997.

[351] J. G. Christensen, T. L. Goldsworthy, and R. C. Cattley, "Dysregulation of apoptosis by c-myc in transgenic hepatocytes and effects of growth factors and nongenotoxic carcinogens," Molecular Carcinogenesis, vol. 25, no. 4, pp. 273-284, 1999.

[352] D. W. Macy and M. J. Hendrick, "The potential role of inflammation in the development of postvaccinal sarcomas in cats," The Veterinary Clinics of North America. Small animal practice, vol. 26, no. 1, pp. 103-109, 1996.

[353] M. J. Day, H. A. Schoon, J. P. Magnol et al., "A kinetic study of histopathological changes in the subcutis of cats injected with non-adjuvanted and adjuvanted multi-component vaccines," Vaccine, vol. 25, no. 20, pp. 4073-4084, 2007.

[354] F. Jelínek, "Postinflammatory sarcoma in cats," Experimental and Toxicologic Pathology, vol. 55, no. 2-3, pp. 167-172, 2003.

[355] M. Kool, T. Soullié, M. van Nimwegen et al., "Alum adjuvant boosts adaptive immunity by inducing uric acid and activating inflammatory dendritic cells," Journal of Experimental Medicine, vol. 205, no. 4, pp. 869-882, 2008.

[356] V. Tittes-Rittershaus, H. de Vries, and H. de Jong, "Local reaction studies in rabbits and dogs," in Trends in Pharmacology and Toxicology, Proceedings of the 1st European Congress, pp. 41-46, Zeist, The Netherlands, September 1979.

[357] E. Murasugi, H. Koie, M. Okano, T. Watanabe, and R. Asano, "Histological reactions to microchip implants in dogs," Veterinary Record, vol. 153, no. 11, pp. 328-330, 2003.

[358] M. Linder, S. Hüther, and M. Reinacher, "In vivo reactions in mice and in vitro reactions in feline cells to implantable microchip transponders with different surface materials," Veterinary Record, vol. 165, no. 2, pp. 45-50, 2009.

[359] G. N. Rao and J. Edmondson, "Tissue reaction to an implantable identification device in mice," Toxicologic Pathology, vol. 18, no. 3, pp. 412-416, 1990.

[360] H. Tazawa, M. Tatemichi, T. Sawa et al., "Oxidative and nitrative stress caused by subcutaneous implantation of a foreign body accelerates sarcoma development in $\operatorname{Trp} 53^{+/-}$ mice," Carcinogenesis, vol. 28, no. 1, pp. 191-198, 2007.

[361] N. Banerji and S. Kanjilal, "Somatic alterations of the p53 tumor suppressor gene in vaccine-associated feline sarcoma," American Journal of Veterinary Research, vol. 67, no. 10, pp. 1766-1772, 2006.

[362] N. Banerji, V. Kapur, and S. Kanjilal, "Association of germline polymorphisms in the feline p53 gene with genetic predisposition to vaccine-associated feline sarcoma," Journal of Heredity, vol. 98, no. 5, pp. 421-427, 2007.

[363] P. R. Nambiar, M. L. Jackson, J. A. Ellis, B. J. Chelack, B. A. Kidney, and D. M. Haines, "Immunohistochemical detection of tumor suppressor gene $\mathrm{p} 53$ protein in feline injection siteassociated sarcomas," Veterinary Pathology, vol. 38, no. 2, pp. 236-238, 2001. 
[364] A. Nieto, M. A. Sánchez, E. Martínez, and E. Rollán, "Immunohistochemical expression of p53, fibroblast growth factor- $b$, and transforming growth factor- $\alpha$ in feline vaccineassociated sarcomas," Veterinary Pathology, vol. 40, no. 6, pp. 651-658, 2003.

[365] S. Cerda and S. A. Weitzman, "Influence of oxygen radical injury on DNA methylation," Mutation Research, vol. 386, no. 2, pp. 141-152, 1997.

[366] R. A. Floyd, "Role of oxygen free radicals in carcinogenesis and brain ischemia," FASEB Journal, vol. 4, no. 9, pp. 25872597, 1990.

[367] B. D. Goldstein and G. Witz, "Free radicals and carcinogenesis," Free Radical Research Communications, vol. 11, no. 1-3, pp. 3-10, 1990.

[368] M. E. Kerr, C. M. Bender, and E. J. Monti, "An introductioon to oxygen free radicals," Heart and Lung, vol. 25, no. 3, pp. 200-209, 1996.

[369] J. E. Klaunig, Y. Xu, J. S. Isenberg et al., "The role of oxidative stress in chemical carcinogenesis," Environmental Health Perspectives, vol. 106, no. 1, supplement, pp. 289-295, 1998.

[370] V. D. Moyer, C. A. Cistulli, C. A. Vaslet, and A. B. Kane, "Oxygen radicals and asbestos carcinogenesis," Environmental Health Perspectives, vol. 102, no. 10, supplement, pp. 131136, 1994.

[371] L. Nasir, G. R. Rutteman, S. W. J. Reid, C. Schulze, and D. J. Argyle, "Analysis of p53 mutational events and MDM2 amplification in canine soft-tissue sarcomas," Cancer Letters, vol. 174, no. 1, pp. 83-89, 2001.

[372] B. Mayr, J. Blauensteiner, A. Edlinger et al., "Presence of p53 mutations in feline neoplasms," Research in Veterinary Science, vol. 68, no. 1, pp. 63-70, 2000.

[373] A. Setoguchi, T. Sato, K. Minehata et al., "Aberrations of the p53 tumor suppressor gene in various tumours in dogs," American Journal of Veterinary Research, vol. 62, no. 3, pp. 433-439, 2001.

[374] S. Liu, L. Xu, T. Zhang, G. Ren, and Z. Yang, "Oxidative stress and apoptosis induced by nanosized titanium dioxide in PC12 cells," Toxicology, vol. 267, no. 1-3, pp. 172-177, 2010.

[375] K. C. Sorensen, B. E. Kitchell, D. J. Schaeffer, and P. E. Mardis, "Expression of matrix metalloproteinases in feline vaccine site-associated sarcomas," American Journal of Veterinary Research, vol. 65, no. 3, pp. 373-379, 2004.

[376] A. Raz, G. Levine, and Y. Khomiak, "Acute local inflammation potentiates tumor growth in mice," Cancer Letters, vol. 148, no. 2, pp. 115-120, 2000.

[377] P. J. A. Borm and K. Driscoll, "Particles, inflammation and respiratory tract carcinogenesis," Toxicology Letters, vol. 88, no. 1-3, pp. 109-113, 1996.

[378] D. W. Kamp, "Asbestos-induced lung diseases: an update," Translational Research, vol. 153, no. 4, pp. 143-152, 2009.

[379] V. L. Kinnula, "Oxidant and antioxidant mechanisms of lung disease caused by asbestos fibres," European Respiratory Journal, vol. 14, no. 3, pp. 706-716, 1999.

[380] C. B. Manning, V. Vallyathan, and B. T. Mossman, "Diseases caused by asbestos: mechanisms of injury and disease development," International Immunopharmacology, vol. 2, no. 2-3, pp. 191-200, 2002.

[381] H. Nagai and S. Toyokuni, "Biopersistent fiber-induced inflammation and carcinogenesis: lessons learned from asbestos toward safety of fibrous nanomaterials," Archives of Biochemistry and Biophysics, vol. 502, no. 1, pp. 1-7, 2010.
[382] M. Carbone and C. W. M. Bedrossian, "The pathogenesis of mesothelioma," Seminars in Diagnostic Pathology, vol. 23, no. 1, pp. 56-60, 2006.

[383] R. T. Carter, C. Giudice, R. R. Dubielzig, and C. M. H. Colitz, "Telomerase activity with concurrent loss of cell cycle regulation in feline post-traumatic ocular sarcomas," Journal of Comparative Pathology, vol. 133, no. 4, pp. 235-245, 2005.

[384] R. R. Dubielzig, "Ocular neoplasia in small animals," Veterinary Clinics of North America, vol. 20, no. 3, pp. 837-848, 1990.

[385] R. R. Dubielzig, "Ocular sarcoma following trauma in three cats," Journal of the American Veterinary Medical Association, vol. 184, no. 5, pp. 578-581, 1984.

[386] C. J. Zeiss, E. M. Johnson, and R. R. Dubielzig, "Feline intraocular tumors may arise from transformation of lens epithelium," Veterinary Pathology, vol. 40, no. 4, pp. 355-362, 2003.

[387] C. M. Bell, T. Schwarz, and R. R. Dubielzig, "Diagnostic features of feline restrictive orbital myofibroblastic sarcoma," Veterinary Pathology. In press.

[388] B. S. Groskopf, R. R. Dubielzig, and S. L. Beaumont, "Orbital extraskeletal osteosarcoma following enucleation in a cat: a case report," Veterinary Ophthalmology, vol. 13, no. 3, pp. $179-183,2010$.

[389] U. Heininger, "A risk-benefit analysis of vaccination," Vaccine, vol. 27, no. 6, supplement, pp. G9-G12, 2009. 

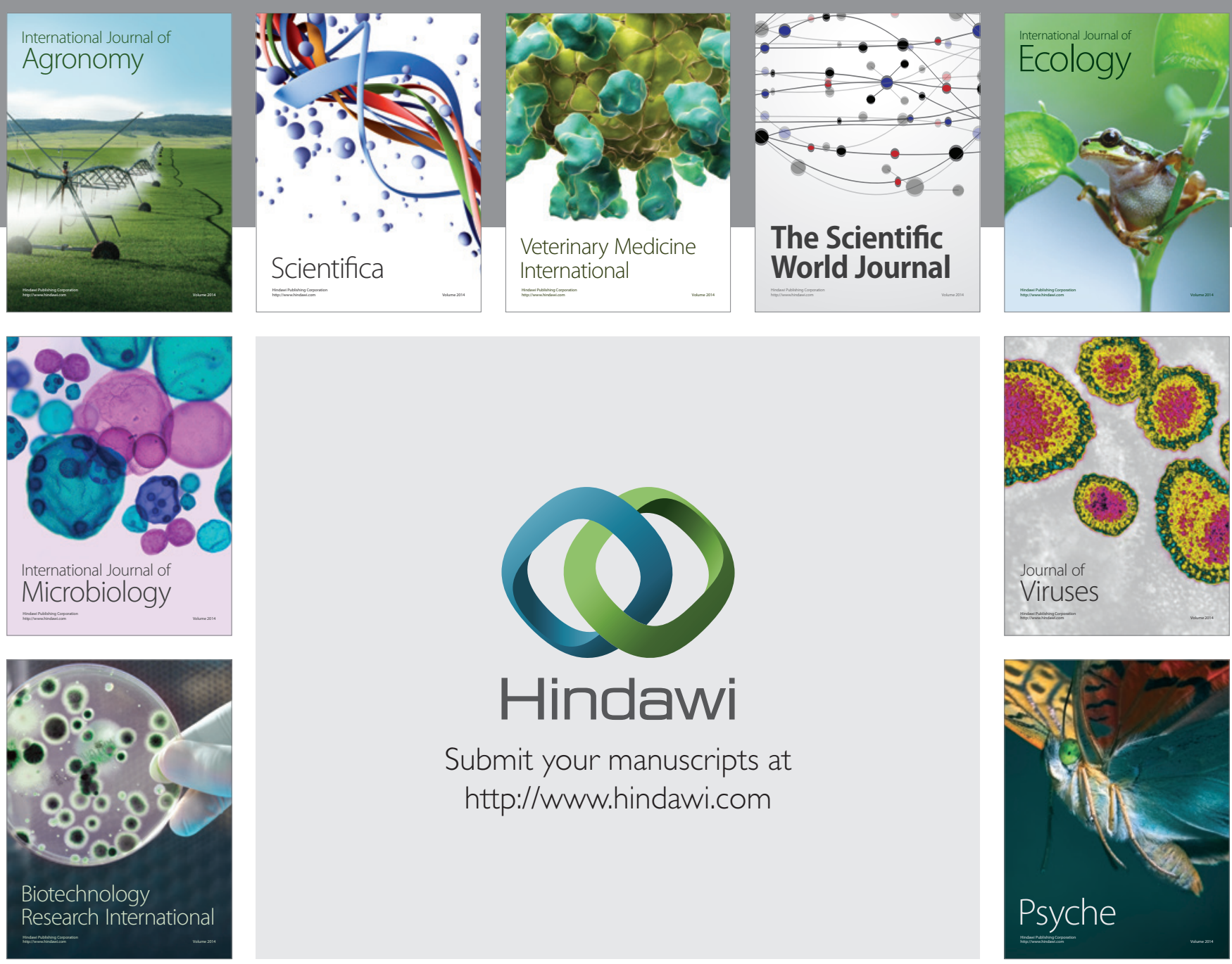

Submit your manuscripts at http://www.hindawi.com
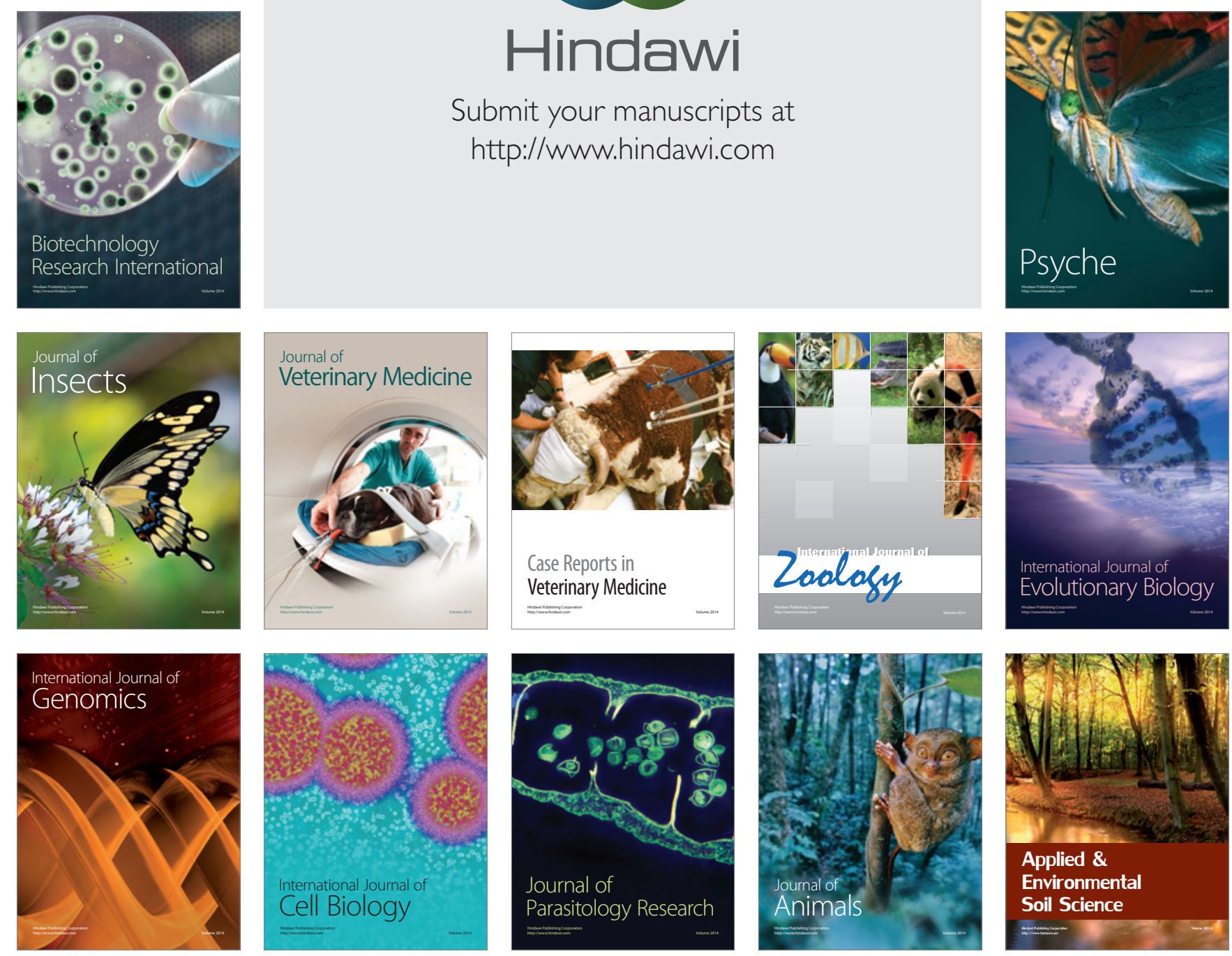